\title{
Religion and Labor Market Performance: Is It What You Believe or How Much?
}

\author{
Philipp Öhlmann ${ }^{1,2,3}$
}

check for updates

Citation: Öhlmann, Philipp. 2021. Religion and Labor Market Performance: Is It What You Believe or How Much?. Religions 12: 102. https://doi.org/10.3390/rel12020102

Academic Editor: Stefan Huber Received: 9 December 2020

Accepted: 28 January 2021

Published: 3 February 2021

Publisher's Note: MDPI stays neutral with regard to jurisdictional claims in published maps and institutional affiliations.

Copyright: (C) 2021 by the author. Licensee MDPI, Basel, Switzerland. This article is an open access article distributed under the terms and conditions of the Creative Commons Attribution (CC BY) license (https:/ / creativecommons.org/licenses/by/ $4.0 /)$.
1 Research Programme on Religious Communities and Sustainable Development, Humboldt-Universität zu Berlin, Unter den Linden 6, 10099 Berlin, Germany; philipp.oehlmann@hu-berlin.de

2 Faculty of Theology and Religion, University of Pretoria, Lynnwood Rd, Hatfield, Pretoria 0002, South Africa

3 Institute for the Study of Christian Social Service (DWI), Heidelberg University, Karlstr. 16, 69117 Heidelberg, Germany

\begin{abstract}
A growing corpus of literature has explored the influence of religion on economic attitudes and behavior. The present paper investigates the effect of religion on labor market performance using a novel approach to control for the endogeneity of religion. It proposes contingency experience, individual experiences of existential insecurity, as an instrumental variable of a person's religiosity. The empirical analysis uses data from a household survey in South Africa specifically designed for this study. The econometric approach is the estimation of instrumental variable ordered probit and linear probability models. Using the Centrality of Religiosity Scale (CRS), the analysis differentiates between effects of individual religious intensity and of religious affiliation. The findings show that individual religiosity, measured in the CRS, has a robust and positive effect on labor market performance. Religious affiliation does not seem to affect labor market performance. The positive effect on religiosity is documented in a set of ordered and binary outcome models across different indicators of labor market performance. The study concludes that the intensity of belief exerts an influence on labor market attitudes and outcomes, while affiliation in religious communities (indicating different content of belief) does not seem to make a difference.
\end{abstract}

Keywords: religion; religiosity; Centrality of Religiosity Scale; labor market performance; contingency experience; instrumental variables; South Africa

\section{Introduction}

The most prominent study on the influence of religion on economic attitudes and outcomes is Max Weber's The Protestant Ethic and the Spirit of Capitalism (Weber [1920] 1958). Weber argued that the Protestant Reformation produced so decisive a shift in individual economic attitudes that it caused the emergence of capitalist economic thinking. Since its first publication in 1904, Weber's hypothesis has received widespread attention from various academic disciplines, albeit without unanimous conclusions regarding its validity (Basten and Betz 2013; Becker and Woessmann 2009; Cantoni 2015). Already, Weber's original study was a reaction to the Marxist school of dialectic materialism, which considered religion to be part of a social superstructure that inhibited social and economic progress (Marx [1843] 1972). The common assumption of both schools of thought is that religion does play an important role in shaping individual attitudes and motivations.

Recently, economic research has increasingly (re-)recognized religion as a potential determinant of economic attitudes and outcomes (Barro and McCleary 2003; Chen and Hungerman 2014; Guiso et al. 2003). Thus far, the results do not provide general answers (Bettendorf and Dijkgraaf 2011). What seems to emerge is that religious beliefs influence attitudes and economic performance in ambiguous ways. The directions and magnitudes of the effects of religion on individual mindsets and actions in the economic realm depend on the religious community in question and, importantly, the social, economic, political, and cultural context. Moreover, central methodological issues remain unresolved. The 
first issue is the identification of causal effects, due to the potential endogeneity of religion (Benjamin et al. 2016). Ex ante attitudes might drive both individual religiosity and labor market performance (cf. Iannaccone 1998), or economic success might affect religious behavior (Buser 2015). Since experimental approaches are seldom feasible, ${ }^{1}$ instrumental variable approaches are frequently used to control for bias due to omitted variables and reverse causality (Beck and Gundersen 2016; Cornelissen and Jirjahn 2012; Gruber 2005). The challenge is finding adequate instruments correlated with religiosity but uncorrelated with economic outcomes. Second, most research relies on religious affiliation as the sole indicator of religion. More sophisticated and multidimensional measures might improve our understanding of the interaction of religion and economics (Lehrer 2009). Third, there is a substantial gap when it comes to evidence from developing and transforming economies, even though religion often plays a more prominent role in these contexts in private and public life than in developed countries (Selinger 2004). Thus far, most of the research on economics and religion has focused on the United States and, to a lesser extent, Europe (Beck and Gundersen 2016). Fourth, it is not clear through which mechanisms religion transmits to economic attitudes and behavior (De Jong 2011).

From a conceptual perspective, the transmission mechanisms from religion to economic outcomes can be related to three levels: the individual, the social, and the institutional (Figure 1). At the individual level, which is the focus of this article, religion transmits to economic outcomes through changed attitudes (Audretsch et al. 2013; Berger 2010; Brañas-Garza et al. 2009; Dickow 2012; Freeman 2012; Guiso et al. 2003; Heuser 2013; Kirchmaier et al. 2018; Mafuta 2010; Meyer 2004). Religion influences motivations and work ethic, leading to economically conducive behavior affecting, for example, labor market performance. Essentially, this relates to Weber 's ([1920] 1958) hypothesis of the Protestant ethic. Weber argued that, in early modern Protestantism, the economically favorable doctrines of "calling," "predestination," and "inner-worldly asceticism" transformed into behavioral patterns that promoted the development of the capitalist economy. A crucial (but often overlooked) point in the Protestant ethic hypothesis is that the prerequisite for the changes in mindsets and behavior brought about by the Reformation was an increase in religiosity (Schilling 2016). As Weber ([1920] 1958) pointed out:

"The Reformation meant not the elimination of the Church's control over everyday life, but rather [...] the repudiation of a control which was very lax, at that time scarcely perceptible in practice and hardly more than formal, in favour of a regulation of the whole conduct which, penetrating to all departments of private and public life was infinitely burdensome and earnestly enforced. [...] And what the reformers complained of in those areas of high economic development was not too much supervision of life on the part of the church, but too little."

Hence, when using Weber's theory to undergird empirical work, the degree of religiosity must be considered in addition to specific theological tenets. Eisenstadt's (1968) notion of the "transformative capacity" of religion provides a generalization of the Protestant ethic applicable to other religious contexts.

In addition to fostering work ethic, religion has a psychosocial support function. Religion can provide identity and increase resilience against adverse shocks (e.g., Cross et al. 1993; Masondo 2013, 2014), which is particularly relevant in developing country contexts marked by high social dynamics, risk, and adversity. Religion becomes a coping mechanism for adversity and contingencies (Ano and Vasconcelles 2005; Pargament 1997). ${ }^{2}$

1 Recent exceptions are the studies by Bryan et al. (2021), who conducted a randomized controlled trial of a religious training component in the Philippines, and studies using laboratory experiments, such as that by Benjamin et al. (2016) for university students in the US.

2 This need not always be the case, as Becker and Woessmann's (2018) recent study on Protestantism and suicide shows. 


\section{RELIGION}

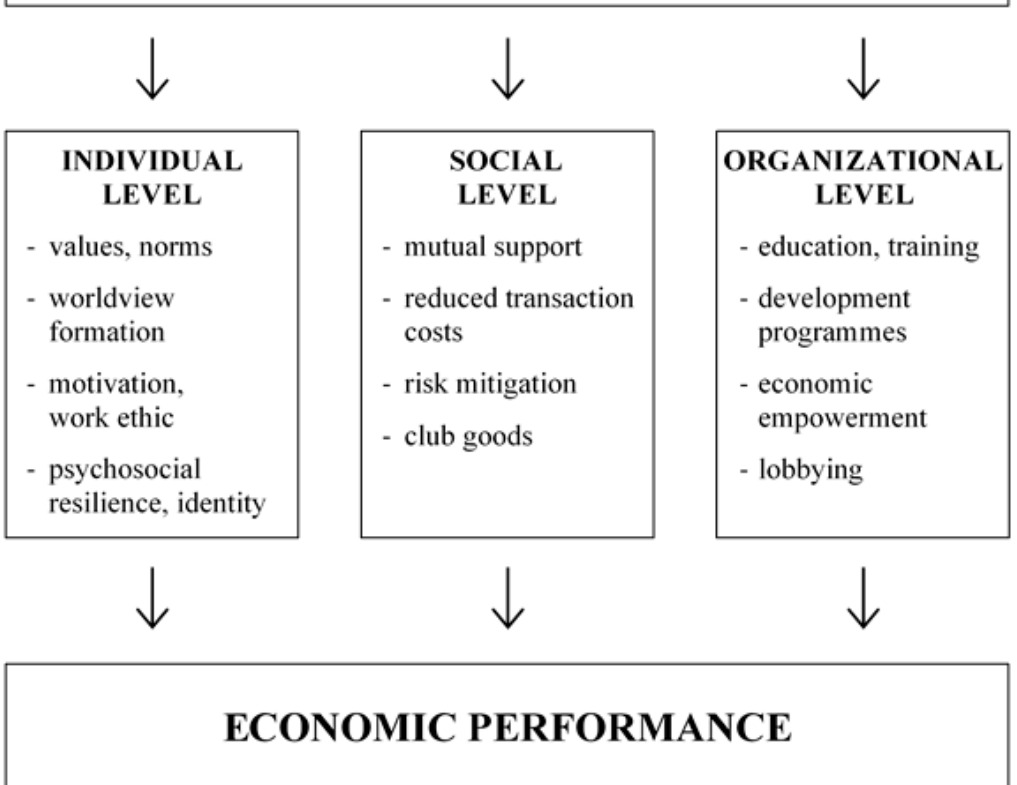

Figure 1. Transmission mechanisms from religion to economic outcomes. Note-Author's elaboration based on Haynes (2009) and Öhlmann et al. (2016). While the separation of the three dimensions is a useful analytical tool, it should be noted that the three dimensions are intertwined in practice and in the self-understanding of most religious communities.

The social level refers to social capital. Religious networks constitute social capital resources (Öhlmann et al. 2016; Swart 2017). These networks can be used for economic improvement and can facilitate collective action (Woolcock 1998). First, religious networking reduces transaction costs. Cross et al. (1993) showed that religious communities constitute sources of labor-market-related information. Second, they are mutual support groups for economic activities (Oosthuizen 1997; Schlemmer 2008). Third, they have an insurance function and serve as a form of risk mitigation (Dehejia et al. 2007). Religious communities constitute support groups in case of adverse shocks. Fourth, they provide implicit club goods, such as the reputation of being reliable and hard-working (Freeman 2012; Mafuta 2010; Turner 1980). At the institutional level, religious communities are important providers of social services. They provide healthcare, education, training, and development programs (Bengtsson 2013; Coleman 1988; Gifford 2015; Öhlmann et al. 2016). Moreover, religious communities lobby in the interests of their members and the wider communities (Bompani 2010; Thomsen 2017).

This paper approaches the relationship of religion and economic attitudes and actions by investigating the effect of religion on labor market performance in South Africa. A household survey was conducted for the specific purpose of this study, enabling us to address shortcomings in the existing literature. First, this study uses a novel method to account for potential endogeneity of religion. I propose that a person's contingency experiences (Lübbe 2004; Luhmann 1982) — that is, experiences of "existential insecurity" (Norris and Inglehart 2011), such as natural catastrophes and death-constitute relevant and valid instruments for religiosity. Recent research has shown that experience of contingencies is one of the factors affecting religiosity and religion is a means of coping with these experiences (Ano and Vasconcelles 2005; Bentzen 2019, 2020; Pargament 2012; Zapata 2018). In the econometric approach, I use contingency experiences as an exogenous variable that produces a variation in the level of individual religiosity (see Section 5.2 for a compre- 
hensive discussion). ${ }^{3}$ This assumption seems particularly justified in the context of South Africa, in which religious worldviews are salient in society (see Section 3).

Second, this study is the first to employ the Centrality of Religiosity Scale (CRS, Huber 2003; Huber and Huber 2012) in an economic study of religion and economic performance at the microeconomic level. Using the CRS allows us to elucidate the individuallevel transmission mechanisms of religion to labor market performance. Conceptually sub-dividing individual religiosity into content ("what you believe") and the intensity of belief ("how much"), I differentiate between the effect of specific religious tenets and individual religiosity. ${ }^{4}$ Third, this study uses cross-sectional data from South Africa, providing evidence from a developing country context.

South Africa is an ideal case study setting due to its highly dynamic religious landscape, particularly within the Christian faith. Research in theology and sociology of religion holds the belief systems of various religious communities in South Africa to be conducive to individual economic outcomes. There is particularly strong support for this relationship in the case of so-called African Independent and Pentecostal-Charismatic churches. In what Anderson (2001) termed "African Reformation," these churches grew from marginal to majority religion in South Africa (and many other African countries) during the twentieth century (Öhlmann et al. 2016). They foster an intensive religiosity. Religion becomes a major determinant of attitudes and actions in the economic realm (Freeman 2012; Turner 1980). This resonates with the Protestant ethic hypothesis by Weber (Berger 2010; Schilling 2016; Weber [1920] 1958).

Moreover, the determinants of labor market performance in South Africa remain of crucial concern. Unemployment in the economically active population is at $26.7 \%$. Including discouraged jobseekers, the figure rises to 36.3\% (Statistics South Africa 2018). Particularly in rural areas and for youth, the figures are even higher. While the living conditions of the majority have improved since the end of apartheid in 1994, over 55\% of the South African population lives below the poverty line of the equivalent of USD $72^{5}$ per month (Statistics South Africa 2017). Inequality continues to be among the highest worldwide (World Bank 2018). In this context, factors contributing to individual labor market success are particularly relevant. Can religion be considered one of these factors?

Research from economics, social sciences, and humanities argues that religion influences economic outcomes in various ways. Following most of the economic research in the field, this study focuses on two different aspects within the dimension of individual religiosity. First, I analyze the effect of different theological tenets and practices by including indicator variables for categories of churches and the practice of African traditional religion. Second, I investigate the effect of generic religiosity (i.e., religious intensity) by employing the Centrality of Religiosity Scale as an explanatory variable. My empirical approach is the estimation of instrumental variable ordered probit and linear probability models of different labor market outcomes (looking for work, working in the informal sector, and working in the formal sector) using data from 1086 working-age individuals in four South African provinces.

Our findings confirm parts of the Weberian hypothesis and findings from sociology of religion, anthropology, and theology on religion in developing countries. The results show that individual religiosity positively affects labor market performance at various levels. This effect seems to be due to (generic) religiosity and not to specific or particular religious communities. No robust effect of affiliation to specific Christian churches is identified,

3 This does not mean that contingency experiences are the only (or even the most important) determinants of religiosity. Individual religiosity can be determined by a multitude of factors. For the econometric approach employed here, the assumption suffices that contingency experiences lead to variations in individual-level religiosity-while acknowledging the complexity of religiosity as an empirical phenomenon and its manifold determinants. See Section 5.2 for a more comprehensive discussion.

4 See Section 4 for a more comprehensive substantiation of proxying different theological tenets by religious affiliation.

5 All ZAR figures are converted to USD at the rate of 13.85, which was the exchange rate at the end of data collection on 1 August 2016. It is rounded to the nearest USD 1. 
indicating that differences in religious tenets do not make a difference. The results are robust across different specifications.

The remainder of the paper is structured as follows. Section 2 provides an overview of recent economic research on micro-level religion and economic outcomes and attitudes. Section 3 introduces the economic and religious context of this study, while Section 4 describes the data and key analytical concepts. The empirical strategy is outlined in Section 5, followed by the results in Section 6. I discuss the findings and their implications in Section 7, followed by a brief conclusion in; Section 8.

\section{Literature}

\subsection{Religion and Labor Market Outcomes}

Economic research on religion and economic performance can be categorized into macroeconomic (e.g., Barro and McCleary 2003; Mangeloja 2005; McCleary and Barro 2006; Noland 2005) and microeconomic studies (e.g., Bettendorf and Dijkgraaf 2010; Guiso et al. 2003). An interesting special case is historical studies investigating the validity of the Weber hypothesis and exploiting differences between historically Protestant and Catholic regions in Europe (e.g., Basten and Betz 2013; Becker and Woessmann 2009, 2013; Cantoni 2015; Spenkuch 2017). In line with the approach of this paper, the focus of this literature review is on economic studies investigating micro-level effects of religion on labor-market-related variables.

With respect to religion and income in the US, Steen (2004) found that "both men raised as Catholics and men raised as Jews have higher earnings" in the National Longitudinal Survey of Youth 1979 Cohort. In a similar vein, in their analysis of the 2000/2001 National Jewish Population Survey, Chiswick and Huang (2008) found that, for Jewish men, "religious involvement is associated with more favorable labor market outcomes," but "beyond some point religious practice has a negative effect." Beck (2016) analyzed data from the 2005 Panel Study of Income Dynamics in a quantile regression approach, identifying positive associations of religious participation and income among Protestant and Catholic men, while for Catholic women, lower participation goes along with higher wages. The three studies by Steen (2004), Chiswick and Huang (2008), and Beck (2016) control for various observable characteristics in their human capital earnings regressions but do not control for potential endogeneity due to selection on unobservable characteristics or simultaneity. Their results "should thus be interpreted as descriptive rather than causal," as Beck (2016) pointed out. Gruber (2005) proposed to use religious market density (i.e., the population share in a region affiliated with one's religion) as an instrument for religious participation. Using the General Social Survey and census data from the US, he found religious participation to have a positive effect on income and several other economic indicators.

Arano and Blair (2008) considered the relationship between religion and income to be bicausal. Using household survey data from the state of Mississippi, they found that religious intensity increases with income and vice versa. They use a simultaneous equation framework to account for the endogeneity of religious intensity with respect to income and the endogeneity of income with respect to religious intensity. While their simultaneous equation approach is similar to the econometric framework of the state-level macroeconomic study by Lipford and Tollison (2003), the results diverge. Lipford and Tollison (2003) found that religious participation decreases labor supply and thus negatively affects state-level per capita income in the US. A simultaneous equation framework is also employed by Bettendorf and Dijkgraaf (2011) in their analysis of Dutch household survey data. They found religious membership and participation to have no effect on income and vice versa. In a more general approach using European and World Values Survey data from 25 countries, the same authors concluded that "church membership is found to have a positive effect on income for high-income countries," while "this effect is negative for low-income countries" (Bettendorf and Dijkgraaf 2010). Using data from the German Socio-Economic Panel Survey, Cornelissen and Jirjahn (2012) found that "being raised by two religious parents, but having no current religious affiliation is associated with higher 
earnings." They control for potential endogeneity by instrumenting religious affiliation with having grown up in a rural area. Spenkuch (2017) exploited a sixteenth century peace treaty, which determined the religion to be either Protestantism or Catholicism in a given region of Germany to account for endogeneity in religion. For the German case, the author found that Protestants work longer hours than Catholics, while there is no difference in hourly wages.

Evidence on religion and labor-market-related outcomes in developing countries is limited. Adeyem et al. (2016) documented a positive effect of religion on female labor market participation in Nigeria on the basis of Demographic and Health Survey data. Permani (2011) identified positive effects of religious social capital on earnings using household survey data from Indonesia. She controlled for unobservable selection using a Heckman (1979) correction for selection bias. This method is also the approach used by Öhlmann and Hüttel (2018) in their South African case study. Using household survey data, the authors showed a positive effect of a specific African Independent Church and African traditional religion on household income. The finding of a positive effect of membership in an African Independent Church corresponds to Beck and Gundersen's (2016) findings from the Ghanaian context. Using data from the Ghana Living Standard Survey in a quantile regression approach, they identified positive relationships of religious membership and income for women who are members of African Independent or Pentecostal and Methodist Churches. However, in contrast to Öhlmann and Hüttel (2018), they identified a negative effect of African traditional religion. To account for endogeneity, Beck and Gundersen (2016) used the religious density in the sampling cluster as an instrument. An entirely different identification strategy is employed by Bryan et al. (2021). The authors conducted a randomized controlled trial of a training program by an evangelical Protestant nongovernmental organization in the Philippines, which encompasses both a Christian values component and a (non-religious) health and livelihoods component. They investigated the effect of the training on persons receiving either one of those components or both components together. Their results demonstrated that the Christian values component increases religiosity and income, while there is no effect on other economic indicators, such as consumption or total labor supply. The values component decreases perceived economic status. At the same time, the health and livelihoods component has no effect on any of the indicators.

\subsection{Religion and Labor-Market-Related Attitudes}

In one of the most influential studies in the area of religion and economic performance, Guiso et al. (2003), focused on economic attitudes. Using World Values Survey data from 66 countries, the authors found that religious upbringing, religiosity, and religious practice promote economically conducive attitudes. Combining World Values Survey and European Values Survey data to comprise 82 countries, van Hoorn and Maseland (2013) investigated the existence of a Protestant work ethic by examining the effect of unemployment on subjective wellbeing. They found that "unemployment hurts Protestants more and hurts more in Protestant countries." Kirchmaier et al. (2018) used survey data from the Netherlands to analyze the relationship of religious participation on various economic behavioral outcomes. Their findings are robust to the use of an instrumental variable model using parents' religiosity as the instrument. They showed that religious participation is associated with ethical behavior and lower preference for redistribution. In an additional behavioral experiment, they found that religious participation does not increase anonymous trust. Economically conducive attitudes were also the focus of BrañasGarza et al. (2009). They highlighted that, in Latin America, religious practice correlates with trust in other people and in public and economic institutions. Audretsch et al. (2013) investigated entrepreneurial attitudes using the 2004 Employment-Unemployment Survey in India. They concluded that "religions like Islam and Jainism are more favorable for self-employment," while "Hindus are less likely to be self-employed." Using behavioral experiments, Benjamin et al. (2016) also found diverging effects of religion on economic 
attitudes. They increased the respondents' religious salience using religious priming, thus creating an exogenous variation in their religiosity. The authors found that "priming causes Protestants to increase contributions to public goods, whereas Catholics decrease contributions to public goods, expect others to contribute less to public goods, and become less risk averse." Religious priming has no effect on other outcomes, such as work effort or generosity.

In summary, there are no unanimous conclusions on the relationship of religion and economic attitudes and outcomes. While the larger part of the microeconomic research in the field seems to point toward positive effects of religion, the identified correlations and effects are diverse. One core methodological issue is the choice of variables for religion. Most studies rely either on membership indicators, frequency of worship attendance, or self-reported intensity of beliefs. Of those mentioned above, only the studies by Arano and Blair (2008) and Guiso et al. (2003) use more comprehensive measures of religiosity. The present study broadens this strand of research using the Centrality of Religiosity Scale, as a multidimensional and interreligious measure of religiosity (Huber et al. 2020; Huber and Huber 2012).

The identification of causal effects of religion remains a challenge in the literature. The potential endogeneity due to unobserved variables and simultaneity is often not dealt with. Of the 19 studies cited above using observational data, eight do not account for endogeneity at all, four use a simultaneous equation framework, five use instrumental variable approaches, and two use a Heckman (1979) approach to correct for selectivity issues (the other two studies are special cases, an experimental study, and a randomized controlled trial). The most common instruments for religion are geographical factors, such as regional religious density (Beck 2016; Gruber 2005), distance from Muslim schools (Permani 2011), or rural area upbringing (Cornelissen and Jirjahn 2012). Öhlmann and Hüttel (2018) used the relationship with a local chief, and Kirchmaier et al. (2018) used parents' religious participation. Experimental approaches, such as the one used by Benjamin et al. (2016), provide an alternative solution, but are limited to quite specific laboratory conditions. Bryan et al. (2021) successfully demonstrated that randomized controlled trials can be used to identify effects of religion. While this is a promising avenue that future research should certainly build on, the approach is limited to specific interventions. This study instead proposes a novel approach that relies on instrumental variables based on contingency experiences and is relatively easy to apply in cross-sectional or panel surveys.

\section{Labor Market and Religion in South Africa}

With a Gini coefficient of 0.63 (2015), South Africa remains among the most unequal societies of the world (World Bank 2018). While the living conditions of the majority have improved since the end of apartheid in 1994, over 55\% of the South African population lives below the poverty line of roughly USD 72 per month (Statistics South Africa 2017). South Africa's economy has a dual nature (African Development Bank 2018), in the words of its former president Thabo Mbeki, divided into a "first world economy" and a "third world economy" (Mbeki 2003). This is reflected in the dichotomous structure of the country's labor market. The upper $10 \%$ of the working population earns wages at the levels of high-income countries from relatively secure formal employment. Wages at the lower end of the distribution are at the levels of the poorest countries in the world, and employment is informal and insecure (World Bank 2018). In the literature on the South African informal sector, it is generally accepted that informal economic activity, consisting mostly of micro businesses, is only a second-best option to formal sector economic activity (Davies and Thurlow 2010; Nackerdien and Yu 2019). This is not surprising considering that half of the informal businesses had a turnover of around USD 108 per month and only around 10\% made monthly profits of over USD 430 (Statistics South Africa 2014). Moreover, South Africa has extremely high unemployment. The official unemployment figure of $26.7 \%$ of the economically active population hides a large number of discouraged jobseekers. When including them in the category of unemployed, the figure rises to 
36.3\% (Statistics South Africa 2018). While the high levels of unemployment are likely to have structural causes (Banerjee et al. 2008; World Bank 2018), the question remains as to what determines whether an individual manages to access the formal labor market or, as a second-best option, engages in informal economic activity. Sociodemographic characteristics and education are key factors in determining both labor force participation and individual labor market success. Racial discrimination continues to play a role as well (Branson and Leibbrandt 2013; World Bank 2018). Thus far, no economic study has investigated the role of religion in this context.

Religion is an important factor in South African society, having high relevance in both public and private life. According to the 2001 census (thus far, the most recent including religious affiliation), $80 \%$ of the South African population are affiliated with Christian churches, around $15 \%$ have no religion, and the remainder are members of other religions, such as Islam and Hinduism (Statistics South Africa 2004). Elements of African traditional religion (ancestral belief systems) and Christianity are often practiced alongside each other. Average levels of religiosity are high in South Africa and religious worldviews are common. Seventy-four percent of South Africans consider religion very important in their lives (Pew Forum 2010). In the Livelihoods, Religion and Youth Survey dataset used here, the mean value of the CRS is 4.03 , indicating that, on average, people are highly religious and only $1.84 \%$ of the survey sample falls into the category non-religious.

Within the Christian faith, the religious landscape is both highly diverse and dynamic. Mission-initiated churches (Catholics and historic Protestant denominations) are found along with African Independent and Pentecostal churches. New churches emerge, and conversion from one church to another-often multiple times in a lifetime-is a common phenomenon. The dynamic is particularly high with respect to African Independent and Pentecostal-Charismatic churches, which represent the majority of the population in the country (Öhlmann et al. 2016). As they share common characteristics, they are often summarized as African Initiated Churches or African Initiated Christianity (Anderson 2000; Öhlmann et al. 2016, 2020). While they constitute a heterogeneous movement with diverse theological tenets, research has emphasized their common conducive role in promoting development and economic success. African Initiated Churches foster an intensive spirituality; religion permeates all spheres of life and becomes a determinant of individual economic attitudes, behavior, and actions (Freeman 2012; Turner 1980). They "maintain a magico-religious worldview" (Freeman 2012), connecting their theology to African belief systems and "African religious sensibilities and aspirations" (Asamoah-Gyadu 2015). Thus, the churches have a high "transformative potential" (Eisenstadt 1968). They transform "individual subjectivities", fostering personal transformation and enabling believers to acquire the agency to take their lives in their own hands (Freeman 2012). This goes along with a strong this-worldly orientation; salvation is seen as "here and now" (Anderson 2000; Freeman 2012). In the framework of a "Gospel of Prosperity," particularly the PentecostalCharismatic churches portray material success as divine blessing and promise (Beck and Gundersen 2016; Heuser 2015, 2016). However, material blessings are not expected to come by prayer alone. Ethics of hard work and strict moral codes are fundamental parts of their belief systems (Freeman 2012; Turner 1980). A strong emphasis is put on education and entrepreneurship as key factors for success (Freeman 2012; Öhlmann et al. 2016; Schlemmer 2008; Turner 1980). This goes along with the dense social structure, mutual support, and initiatives to improve individual and communal wellbeing at various levels (Öhlmann et al. 2016).

Several studies on religion and labor-market-related outcomes from the disciplines of theology and sociology of religion indicate that particularly African Independent and Pentecostal-Charismatic churches positively contribute to their members' labor market performance. Cross et al. (1993) highlighted the role of African Independent Churches in the economic empowerment of youth in South African metropolitan areas. The churches provide support to rural-urban migrants through material help, social integration, and the provision of information on economic opportunities. In a similar vein, Oosthuizen (1997) high- 
lighted the role of African Independent Churches in small business support. Mafuta (2010) showed how South Africa's largest religious community, the Zion Christian Church, influences its adherents' individual work ethics, identity, and attitudes. Mafuta argued that their labor market potential is higher than in other churches, inter alia due to their reputation of being hard-working, sober, and reliable. Meyer (2004) showed that the actions and attitudes of adherents of Pentecostal-Charismatic churches change because of their membership in the church. The positive message emphasizing this-worldly salvation and material wellbeing causes them to be "lifted up in social standing, and their lives stabilize." In a large-scale study on Pentecostal churches, Schlemmer (2008) highlighted a high valuation of education, the affirmation of positive ethics in professional and private life, and the promotion of entrepreneurial activity as key features. Similar results with respect to education, training, and entrepreneurship were reported by Dickow (2012). The author concluded that members of Pentecostal-Charismatic churches have high upward social mobility, are geared toward improving their lives, and display an optimistic outlook toward the future. Moreover, they constitute dense social networks. Recently, Öhlmann et al. (2016) investigated African Independent and Pentecostal-Charismatic churches with respect to their potential for development cooperation. They showed that many of these churches provide their members with means to improve their economic situation in material and immaterial ways. The churches are development actors. They not only focus on spiritual realms but also engage in improving the material wellbeing of their members and the wider communities (e.g., through education and training programs). The authors highlighted that these churches focus on enabling people to be economically independent. In summary, there seems to be a consensus in the theological and sociological literature that African Independent and Pentecostal-Charismatic churches have substantial transformative effects on their members' attitudes and actions (Öhlmann et al. 2016). These results correspond to Beck and Gundersen's (2016) findings from the Ghanaian context and Öhlmann and Hüttel's (2018) results from South Africa.

\section{Data and Descriptive Statistics}

To investigate the effect of individual religiosity and different religious tenets on labor market performance in South Africa, a household survey was specifically conducted. The survey focused on predominantly Sepedi- and Setswana-speaking municipalities of Limpopo, North West, Mpumalanga, and Gauteng Provinces of South Africa and took place from June to July 2016. Rural, peri-urban, and urban areas are covered. The sample was restricted to these areas to keep cultural and geographical heterogeneity low. A high number of distorting factors could potentially have impeded the identification of statistically significant effects. Moreover, restricting the sample to areas in which two major South African indigenous languages are dominant allowed conducting interviews in the local languages. Sampling was done in a multi-stage cluster approach based on Statistics South Africa dwelling frame data. Interviews were conducted using a structured questionnaire in English, Sepedi, and Setswana. The survey included 1039 household interviews (comprising 4981 individuals) and 1864 individual interviews. Because of its focus on labor market performance, the analysis presented here uses a subsample of 1086 working-age individuals. It includes all persons between ages 16 and 60 who are out of secondary school (those that have ceased to attend secondary school, regardless of which degree they have completed). The threshold of 60 is selected in line with the minimum retirement age in South Africa. Labor market participation rates decline from that age onwards. Each person from the age of 60 onwards having an annual income below ZAR 69,000 (USD 4982) is entitled to a government old age grant of ZAR 1500 (USD 108) per month (South African Social Security Agency 2016).

Table 1 shows the descriptive statistics of the variables used in the analysis. The data include comprehensive information on sociodemographic characteristics, education, social capital, religion, and economic activity. With respect to religion, comprehensive data are available on religious adherence and individual religiosity. The dataset allows 
for the differentiation of specific categories of Christian churches, as Christianity is the dominant religion in the survey area. Seventy-three percent of the persons in the sample are church members. The main categories of churches are mission-initiated ( $15 \%$ of the sample), Apostolic (14\%), Pentecostal-Charismatic (11\%), and Zion Christian (25\%) churches (cf. Anderson 2000). Each of the church categories is indicative of a set of common theological tenets and practices and hence assumed to be a proxy for religious content. At this point, it needs to be noted that membership indicators might in many contexts be only a weak indicator of different religious content. Aside from the fact that the dataset used for this paper does not include more refined variables on religious content, this is justified because of the specificities of the South African context and the high context relevance of the religious categories employed. In the South African context, conversion from one denomination to another is a relatively frequent phenomenon. Such religious switching takes place because of different theological tenets and practices. In such contexts, affiliation might therefore be a much better indicator of religious content than in those contexts in which religious switching is relatively uncommon and where therefore other factors, such as the role of parents' religious affiliation and religious socialization, play a greater role. Moreover, in the design of the survey, close attention was paid to not imposing pre-determined categories of churches. To ensure a high degree of context-relevance in the categories of religious communities employed here, a qualitative pre-study was conducted before the quantitative data collection. In several focus group discussions taking place in different locations of the survey area, participatory appraisal methods were employed to collect information on the different categories of churches relevant in the local context. The categorization emerging from the pre-study was triangulated with the categories developed by Anderson (2000) in his seminal study on churches in South Africa. Anderson categorizes South African churches based on a comprehensive large-scale survey, which shows belief systems and practices to differ substantially between the categories. It is important to note that the basis for Anderson's categorizations is not official documents or church leadership statements. Rather, churches are categorized based on the individual members' responses to questions on beliefs and practices. The following paragraph briefly describes the resultant categories and their characteristics.

While mission-initiated churches describe the historic Protestant denominations and the Catholic church, which were imported to South Africa through mission and immigrant movements, the latter three categories are part of the wider movement of African Independent and Pentecostal-Charismatic churches portrayed above. Hence, we are able to differentiate between different groups of churches within the broader movement of African Initiated Christianity, similar to Beck and Gundersen (2016). The first category of these churches, Apostolic churches, represents primarily small churches (even though a few larger ones exist as well, such as St John's Apostolic Faith Mission). They originated in the first wave of Pentecostal revival, which swept to South Africa from the US in the first half of the twentieth century. Their theology often has close links to African traditional belief systems (Anderson 2000; Thomas 2007). In terms of their origin in the Pentecostal movement and their reference to African traditional belief systems, they are similar to the second category, Zion Christian churches. However, the Zion Christian churches are two large churches with membership in the millions. The two Zion Christian churches emerged out of a leadership dispute but remain similar in structure and theology. They put strong emphasis on moral guidelines and discipline (e.g., prohibiting the consumption of alcohol, tobacco, and pork), while simultaneously providing spiritual support and promoting agency and self-reliance (Anderson 2000). Pentecostal-Charismatic churches are a group of smaller churches. They emerged in South Africa from the 1980s onwards during the second wave of Pentecostal renewal. While they operate within the framework of a spiritual worldview, they disassociate themselves from any practices related to African traditional religion (Anderson 2000; Freeman 2012). They are also strong advocates of a "Prosperity Gospel" - that is, a theology that portrays material success as a divine blessing attainable by everyone (Heuser 2013). All three categories share the economically 
conducive features outlined in Section 3. The data furthermore include information on the practice of African traditional religion, the second important religion in the region. A unique feature of the data is that they allow for the simultaneity of church membership and traditional religious practice. The overlap of Christianity and African traditional religion is a common phenomenon in South Africa. In our data, 33\% of the respondents are church members and report to be practicing African traditional religion as well. Sixteen percent practice traditional religion only, while $11 \%$ are not affiliated with any religion. Table 2 provides summary statistics by religious affiliation.

Individual religiosity is measured in the Centrality of Religiosity Scale (Huber 2003; Huber and Huber 2012), included in the data as variable CRS. ${ }^{6}$ The CRS is a novel measure of religiosity developed for the international Religion Monitor Survey (Huber 2009; Huber and Krech 2009; Pickel 2013). Studies have shown its interreligious and intercultural applicability (Huber et al. 2020). It measures individual religiosity in five religious core dimensions. Responses to specific questions in each of the dimensions are coded on a scale from 1 to 5 . The mean across the five dimensions constitutes a measure of a person's religiosity. Based on the values, a person can be categorized as "non-religious" (CRS $\leq 2)$, "religious" $(2<C R S>4)$, or "highly religious" (CRS $\geq 4)$. In our data, the interreligious version of the CRS-5, CRSi-7, was adapted to better accommodate spiritual worldviews (Ashforth 2005; Gifford 2015) and African traditional religious practice in the South African context of this study. The questionnaire items 1, 2, 4, and 5 were slightly rephrased to ensure context-relevance and translatability into the local languages Sepedi and Setswana, while careful attention was paid to not changing the meaning of the respective questions. In the intellectual dimension (1), direct reference to "spiritual" issues was included, while in the ideological dimension (2), "something divine" was specified as "ancestors or spirits". Similarly, in dimension (5) (experience), "something divine" was concretized as "ancestors or spiritual forces". In the dimension of public practice (dimension (4)), "religious" services was changed to "church" services. Similar to the CRSi-7, in two dimensions, additional interreligious items were included. In the modified version proposed here, these were specifically designed to relate to African traditional religion. In dimension (3), the original interreligious CRSi-7 item 04b, "How often do you meditate?", was modified to "How often do you praise the ancestors?", and in dimension (4), the additional item, "How often do you take part in African traditional religious activities?", was added. Unlike in the original CRSi-7, no additional item was included in dimension (5). Table 3 provides the full overview of the version of the CRS employed in comparison to the CRS-5.

The mean value of the variable $C R S$ in the dataset is just above 4 (Table 1, Panel II). On average, people in the survey area are highly religious. This corresponds to similar findings from Centrality of Religiosity Scale data from Nigeria (Hock 2009). Table 2 depicts mean religiosity across the different religious communities. Church members are more religious than non-members. The figures confirm findings from sociology of religion indicating that Pentecostal-Charismatic churches foster a particularly high degree of individual religiosity. The hypothesis that members of African Independent and Pentecostal-Charismatic churches are more religious in general does not hold. While mean values of religiosity are higher in the Pentecostal-Charismatic churches and the Zion Christian churches, the difference between Apostolic churches and mission-initiated churches is not statistically significant. Figure 2 shows the distribution of religiosity for the different categories. The distribution for members of Pentecostal-Charismatic churches has the largest skewness toward the highly religious.

6 In the following, CRS (italics) refers to the CRS as a variable used in the empirical part of the paper, while CRS (non-italic) refers to the Centrality of Religiosity Scale as such. 
Table 1. Descriptive statistics.

\begin{tabular}{|c|c|c|}
\hline \multicolumn{3}{|c|}{ (I) Control Variables } \\
\hline & Mean & SD \\
\hline \multicolumn{3}{|l|}{ Sociodemographics: } \\
\hline Age (years) & 36.11 & 12.15 \\
\hline Female (percent) & 63.35 & 48.21 \\
\hline Household head (percent) & 32.23 & 46.76 \\
\hline Disability grant recipient (percent) & 3.59 & 18.62 \\
\hline Child grants received for children in their care (absolute number) & 0.64 & 1.14 \\
\hline Migration history (percent) & 58.84 & 49.24 \\
\hline Sepedi mother tongue (percent) & 47.24 & 49.95 \\
\hline Setswana mother tongue (percent) & 39.41 & 48.89 \\
\hline \multicolumn{3}{|l|}{ Education: ${ }^{a}$} \\
\hline \multicolumn{3}{|l|}{ Secondary education } \\
\hline Secondary school completed (percent) & 53.04 & 49.93 \\
\hline \multicolumn{3}{|l|}{ Tertiary education } \\
\hline Vocational training completed (percent) & 3.31 & 17.91 \\
\hline College certificate completed (percent) & 11.88 & 32.37 \\
\hline College or university diploma completed (percent) & 8.93 & 28.53 \\
\hline University degree completed (percent) & 5.06 & 21.94 \\
\hline Current tertiary enrollment (percent) & 7.73 & 26.73 \\
\hline \multicolumn{3}{|l|}{ Social capital: } \\
\hline Social capital index (absolute number) ${ }^{b}$ & 0.56 & 0.90 \\
\hline \multicolumn{3}{|l|}{ Household composition (household level means) *: } \\
\hline Household size (number of persons) & 5.10 & 2.88 \\
\hline Share of children under 16 in the household & 0.25 & 0.23 \\
\hline Share of additional working-age household members & 0.30 & 0.22 \\
\hline Share of pension grant recipients in the household & 0.06 & 0.15 \\
\hline \multicolumn{3}{|c|}{ (II) Religion Variables } \\
\hline & Mean & SD \\
\hline \multicolumn{3}{|l|}{ Religiosity: } \\
\hline Centrality of Religiosity Scale (CRS) & 4.03 & 0.75 \\
\hline \multicolumn{3}{|l|}{ Religious affiliation: } \\
\hline No religion, base category (percent) & 11.33 & 31.71 \\
\hline African traditional religion (percent) ${ }^{c}$ & 48.16 & 49.99 \\
\hline African traditional religion $\times$ Church membership (percent) & 32.59 & 46.90 \\
\hline African traditional religion $\times$ No church membership (percent) & 15.56 & 36.27 \\
\hline Church membership (percent) & 73.11 & 44.36 \\
\hline Apostolic church membership (percent) & 13.91 & 34.62 \\
\hline Mission church membership (percent) & 15.47 & 36.18 \\
\hline Pentecostal-Charismatic church membership (percent) & 10.86 & 30.90 \\
\hline Zion Christian church membership (percent) & 24.95 & 43.29 \\
\hline Other/unknown church membership (percent) & 08.10 & 27.30 \\
\hline
\end{tabular}

Note-If not specified otherwise, variables are binary indicators $(1=$ yes $/ 0=$ no, with the means and standard deviations provided as percentages). ${ }^{\text {a }}$ Secondary education indicates the completion of 12 years of schooling; tertiary education variables additionally indicate the highest tertiary qualification completed. Completion of a qualification and current enrolment are not mutually exclusive (e.g., in case of postgraduate qualifications). ${ }^{\mathrm{b}}$ Number of memberships in community groups and associations (chief's council, sports club, farmer's union, local citizens' committee, political party). ${ }^{c}$ African traditional religion does not denote affiliation in a strict sense but rather a set of practices. It was operationalized in the survey as "Do you practice African traditional religion? (yes/no)" and is not mutually exclusive with church membership. $\mathrm{N}$ (individuals) $=1086 ;{ }^{*} \mathrm{~N}$ (households) $=759$. 
Table 2. Key summary statistics by church membership and African traditional religion.

\begin{tabular}{|c|c|c|c|c|c|c|c|c|}
\hline & $\begin{array}{l}\text { No Church } \\
\text { Membership }\end{array}$ & $\begin{array}{l}\text { Apostolic } \\
\text { Church }\end{array}$ & $\begin{array}{l}\text { Mission } \\
\text { Church }\end{array}$ & $\begin{array}{l}\text { Pentecostal- } \\
\text { Charismatic } \\
\text { Church }\end{array}$ & $\begin{array}{c}\text { Zion } \\
\text { Christian } \\
\text { Church }\end{array}$ & $\begin{array}{l}\text { Other/Unknown } \\
\text { Church }\end{array}$ & $\begin{array}{c}\text { African } \\
\text { Traditional } \\
\text { Religion }=0\end{array}$ & $\begin{array}{c}\text { African } \\
\text { Traditional } \\
\text { Religion = } 1\end{array}$ \\
\hline Mean age & $\begin{array}{c}34.12 \\
(11.94)\end{array}$ & $\begin{array}{c}37.30 \\
(12.10)\end{array}$ & $\begin{array}{c}38.58 \\
(12.97)\end{array}$ & $\begin{array}{c}32.18 \\
(10.88)\end{array}$ & $\begin{array}{c}37.39 \\
(11.93)\end{array}$ & $\begin{array}{c}37.14 \\
(11.74)\end{array}$ & $\begin{array}{c}36.32 \\
(12.41)\end{array}$ & $\begin{array}{c}35.88 \\
(11.88)\end{array}$ \\
\hline $\begin{array}{c}\text { Proportion } \\
\text { female, } \\
\text { percentage }\end{array}$ & $\begin{array}{c}38.36 \\
(48.71)\end{array}$ & $\begin{array}{c}75.50 \\
(43.15)\end{array}$ & $\begin{array}{c}67.26 \\
(47.07)\end{array}$ & $\begin{array}{l}75.866 \\
(42.98)\end{array}$ & $\begin{array}{c}72.32 \\
(44.82)\end{array}$ & $\begin{array}{c}73.86 \\
(44.19)\end{array}$ & $\begin{array}{c}64.65 \\
(47.85)\end{array}$ & $\begin{array}{c}61.95 \\
(48.60)\end{array}$ \\
\hline $\begin{array}{l}\text { Mean school } \\
\text { years } \\
\text { completed }\end{array}$ & $\begin{array}{r}9.53 \\
(3.47)\end{array}$ & $\begin{array}{l}8.65 \\
(3.71)\end{array}$ & $\begin{array}{l}10.77 \\
(2.80)\end{array}$ & $\begin{array}{l}11.47 \\
(1.33)\end{array}$ & $\begin{array}{l}9.87 \\
(3.33)\end{array}$ & $\begin{array}{l}10.14 \\
(3.15)\end{array}$ & $\begin{array}{l}10.04 \\
(3.26)\end{array}$ & $\begin{array}{l}9.83 \\
(3.29)\end{array}$ \\
\hline $\begin{array}{l}\text { Proportion } \\
\text { with tertiary } \\
\text { qualification, } \\
\text { percentage }\end{array}$ & $\begin{array}{c}23.29 \\
(42.34)\end{array}$ & $\begin{array}{l}15.89 \\
(36.68)\end{array}$ & $\begin{array}{r}38.69 \\
(48.85)\end{array}$ & $\begin{array}{l}38.79 \\
(48.94)\end{array}$ & $\begin{array}{l}31.73 \\
(46.63)\end{array}$ & $\begin{array}{c}32.95 \\
(47.27)\end{array}$ & $\begin{array}{r}32.68 \\
(46.95)\end{array}$ & $\begin{array}{c}25.43 \\
(43.59)\end{array}$ \\
\hline $\begin{array}{l}\text { Proportion } \\
\text { with } \\
\text { migration } \\
\text { history, } \\
\text { percentage }\end{array}$ & $\begin{array}{l}53.08 \\
(49.99)\end{array}$ & $\begin{array}{r}63.58 \\
(48.28)\end{array}$ & $\begin{array}{l}47.62 \\
(50.09)\end{array}$ & $\begin{array}{r}66.38 \\
(47.45)\end{array}$ & $\begin{array}{r}64.58 \\
(47.92)\end{array}$ & $\begin{array}{l}63.64 \\
(48.38)\end{array}$ & $\begin{array}{r}63.77 \\
(48.11)\end{array}$ & $\begin{array}{l}53.54 \\
(49.92)\end{array}$ \\
\hline $\begin{array}{l}\text { Mean social } \\
\text { capital }\end{array}$ & $\begin{array}{c}0.60 \\
(0.96)\end{array}$ & $\begin{array}{c}0.48 \\
(0.80)\end{array}$ & $\begin{array}{c}0.68 \\
(1.06)\end{array}$ & $\begin{array}{c}0.51 \\
(0.82)\end{array}$ & $\begin{array}{c}0.55 \\
(0.86)\end{array}$ & $\begin{array}{c}0.49 \\
(0.79)\end{array}$ & $\begin{array}{c}0.47 \\
(0.78)\end{array}$ & $\begin{array}{c}0.66 \\
(1.02)\end{array}$ \\
\hline Mean CRS & $\begin{array}{c}3.37 \\
(0.78)\end{array}$ & $\begin{array}{c}4.18 \\
(0.56)\end{array}$ & $\begin{array}{c}4.14 \\
(0.61)\end{array}$ & $\begin{array}{c}4.54 \\
(0.48)\end{array}$ & $\begin{array}{c}4.27 \\
(0.55)\end{array}$ & $\begin{array}{c}4.34 \\
(0.57)\end{array}$ & $\begin{array}{c}4.11 \\
(0.79)\end{array}$ & $\begin{array}{c}3.94 \\
(0.70)\end{array}$ \\
\hline $\begin{array}{c}N \\
\text { Percentage of } \\
\text { sample }\end{array}$ & $\begin{array}{c}292 \\
26.89\end{array}$ & $\begin{array}{c}151 \\
13.90\end{array}$ & $\begin{array}{c}168 \\
15.47\end{array}$ & $\begin{array}{c}116 \\
10.68\end{array}$ & $\begin{array}{c}271 \\
24.95\end{array}$ & $\begin{array}{c}88 \\
8.10\end{array}$ & $\begin{array}{c}563 \\
51.84\end{array}$ & $\begin{array}{c}523 \\
48.16\end{array}$ \\
\hline
\end{tabular}

Note-African traditional religion and church membership are not mutually exclusive; analysis of variance shows category values of CRS to be statistically different from the sample average; standard deviation in parentheses; $F=95.71$ (church categories); $F=13.88$ (African traditional religion).

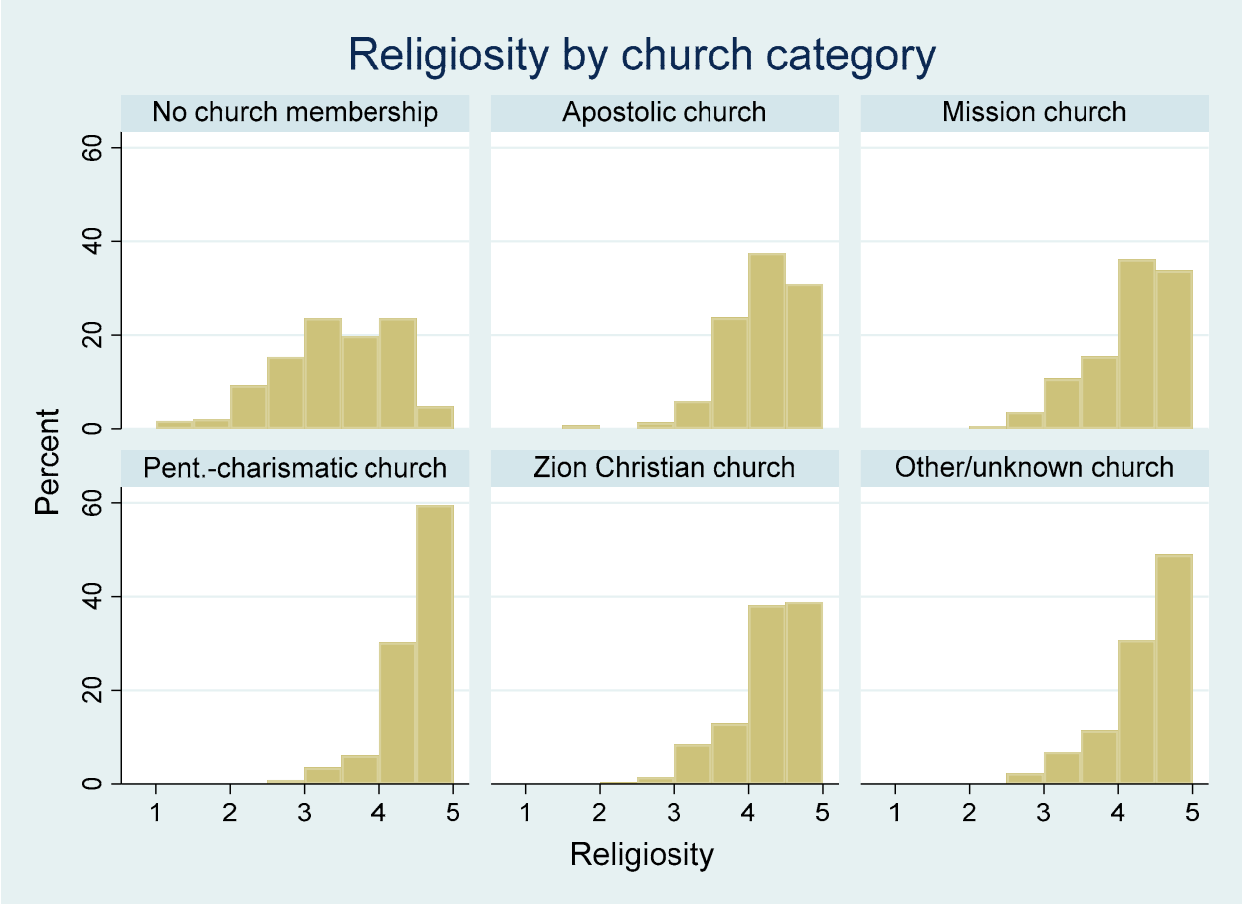

Figure 2. CRS by church category. Note-Figure shows the distribution of individual religiosity according to the different categories of churches in the sample, measured according to the Centrality of Religiosity Scale, CRS (Huber and Huber 2012). A value less than or equal to 2 indicates "non-religious" persons, values between 2 and 4 indicate "religious" persons, while a value equal to or greater than 4 is categorized as "highly religious". 
Table 3. Inventory of the Centrality of Religiosity Scale.

\begin{tabular}{|c|c|c|c|c|}
\hline Religious Core Dimension & Questionnaire Item & Response Codes & Mean & SD \\
\hline Intellect & $\begin{array}{l}\text { How often do you think about } \\
\text { religious and spiritual issues? } \\
\text { *original CRS-5: religious }\end{array}$ & $\begin{array}{c}1=\text { Never } \\
2=\text { Rarely } \\
3=\text { Occasionally } \\
4=\text { Often } \\
5=\text { Very often }\end{array}$ & 3.67 & 1.29 \\
\hline Ideology & $\begin{array}{l}\text { To what extent do you believe that } \\
\text { God or ancestors or spirits* exist? } \\
\text { *original CRS-5: something divine }\end{array}$ & $\begin{array}{c}1=\text { Not at all } \\
2=\text { Not very much } \\
3=\text { Moderately } \\
4=\text { Quite a bit } \\
5=\text { Very much so }\end{array}$ & 4.22 & 1.00 \\
\hline Private practice & $\begin{array}{l}\text { (a) How often do you pray? } \\
\text { Additional interreligious item for African } \\
\text { traditional religion: (b) How often do you } \\
\text { praise the ancestors? }\end{array}$ & $\begin{array}{c}1=\text { Never } \\
2=\text { A few times a year and less } \\
3=\text { One to three times a month } \\
4=\text { More than once a week } \\
5=\text { Once a day or more often }\end{array}$ & 4.60 & 0.96 \\
\hline Public practice & $\begin{array}{c}\text { (a) How often do you take part in } \\
\text { church* services? } \\
\text { *original CRS-5: religious } \\
\text { Additional interreligious item for African } \\
\text { traditional religion: (b) How often do you } \\
\text { take part in African traditional religious } \\
\text { activities? }\end{array}$ & $\begin{array}{c}1=\text { Never } \\
2=\text { A few times a year and less } \\
3=\text { One to three times a month } \\
4=\text { More than once a week } \\
5=\text { Once a day or more often }\end{array}$ & 4.20 & 1.16 \\
\hline Experience & $\begin{array}{l}\text { How often do you experience } \\
\text { situations in which you have the } \\
\text { feeling that God or ancestors or spiritual } \\
\text { forces* intervene in your life? } \\
\text { *original CRS-5: something divine }\end{array}$ & $\begin{array}{c}1=\text { Never } \\
2=\text { Rarely } \\
3=\text { Occasionally } \\
4=\text { Often } \\
5=\text { Very often }\end{array}$ & 3.45 & 1.37 \\
\hline
\end{tabular}

Note-In those dimensions where additional interreligious versions of the questions are available, the higher value is used to compute the value of the CRS. The authors thank Stefan Huber for this helpful advice. The CRS is designed as a measure of intrinsic religiosity (Huber and Huber 2012). However, the dimension of public practice is related to the social dimension of religiosity as well. To avoid the possibility that social religiosity drives the results through public practice, I conducted the following analyses using a four-dimensional CRS, leaving out public practice. As the results do not change substantially, there is no evidence that social religiosity influences the results.

I operationalize contingency experience using a questionnaire inventory focusing on major events experienced in life. First, I compute Contingency experience, an index of the responses to the following four questions:

A. "Have you ever been in situations of incredible joy?"

B. "Have you ever experienced (positive or negative) events in your life that you could not explain?"

C. "Have you ever been in situations of fundamental despair?" and

D. "Have you ever experienced the death or loss of a person close to you?"

All four questions have a yes $=1 / \mathrm{no}=0$ answer option. The responses are aggregated by computing the mean of these four dimensions. Table 4 shows the summary statistics for the individual questions and the index. A second, simpler indicator of experiences of contingency is Experience of death, an indicator variable using only the response to question (D), the experience of death in close social proximity. Using the response to this question alone has the advantage of being less prone to interpretation by the respondents themselves. Both indicators of contingency experience are positively correlated with CRS (Table 4). To further validate that experiences of contingency are predictors of religiosity, I regress CRS on the different dimensions of contingency and the index Contingency experience, including the full set of covariates listed in Table 1 (Panel I). Column (7) in Table 4 shows the results. All dimensions have a significant and positive correlation with $C R S$ when controlling 
for other covariates. Having experienced the loss of a close person increases individual religiosity by $19 \%$ of a standard deviation. Having experienced all four dimensions, as captured in the index Contingency experience, increases CRS by $70 \%$ of a standard deviation.

Table 4. Contingency experience.

\begin{tabular}{|c|c|c|c|c|}
\hline Questionnaire Item & Mean & SD & $\begin{array}{l}\text { Correlation with } C R S \\
\quad(p \text {-Value })\end{array}$ & $\begin{array}{l}\text { OLS Coefficient } \\
\text { (SE) }\end{array}$ \\
\hline $\begin{array}{l}\text { (A) Have you ever been in situations of fundamental } \\
\text { despair? (yes/no) }\end{array}$ & 0.77 & 0.42 & $0.13^{* * *}(0.00)$ & $0.13 *(0.08)$ \\
\hline $\begin{array}{l}\text { (B) Have you ever been in situations of incredible joy? } \\
\text { (yes/no) }\end{array}$ & 0.86 & 0.35 & $0.10^{* * *}(0.00)$ & $0.25^{* *}(0.11)$ \\
\hline $\begin{array}{l}\text { (C) Have you ever experienced (positive or negative) events } \\
\text { in your life that you could not explain? (yes/no) }\end{array}$ & 0.47 & 0.50 & $0.12^{* * *}(0.00)$ & $0.19^{* * *}(0.06)$ \\
\hline $\begin{array}{l}\text { (D) Have you ever experienced the death or loss of a person } \\
\text { close to you? (yes } / \text { no) }\end{array}$ & 0.88 & 0.33 & $0.11^{* * *}(0.00)$ & $0.19 * *(0.09)$ \\
\hline $\begin{array}{l}\text { Index of contingency experience (mean of the four } \\
\text { responses) }\end{array}$ & 0.74 & 0.23 & $0.20^{* * *}(0.00)$ & $0.70^{* * *}(0.14)$ \\
\hline
\end{tabular}

Note-Column 4: Correlation coefficient of CRS and the respective indicator of Contingency experience. Column 5: Regression coefficients from ordinary least squares regression of CRS (dependent variable, standardized) on Contingency experience; covariates include sociodemographic characteristics at individual and household levels, education, social capital, migration, language, and social security grant receipt (see Table 1, Panel I) as well as ward indicators; constant omitted; standard errors in parentheses clustered at household level; $N=1086$; ${ }^{*} p<0.1,{ }^{* *} p<0.05,{ }^{* * *} p<0.01$.

With respect to labor market performance, the dataset offers information on formal and informal (self-)employment. Additionally, labor market attitudes are measured as self-reported job-seeking activity (not looking for work, waiting for work to come, and actively looking for work). This information is summarized in an ordinal scale indicating a person's labor market status. Formal employment or self-employment is given the highest value (3), followed by informal employment or self-employment (2), and actively looking for work (1). The underlying assumption is that a higher value constitutes a better labor market outcome from the individual's point of view. This assumption is justified due to the high unemployment rates in South Africa and the large wage differential between the formal and informal sectors (World Bank 2018). Due to the dual structure of the labor market and the high wage differential between formal and informal labor markets, informal employment is an alternative option for those that have not (yet) found employment in the formal sector. Category 0 includes all individuals not actively looking for work or working (i.e., those reporting "waiting for work to come" or "not looking for work") or $17.4 \%$ of the sample. This category includes two different groups of persons: those who could work in principle but chose not to do so (e.g., because they have given up actively looking for employment) and those who are not able to work (e.g., disabled persons or women with small children). It might be argued that including category 0 in the analysis distorts the results. However, in light of the high portion of discouraged jobseekers in the South African economy and the potential effect of religion on attitudes such as work ethics and motivation documented in sociology of religion, it is vital to include them. Motivational effects of religion can only be identified by differentiating between those that are not actively looking for work and those that are. At the same time, I control for those factors that decrease the probability of actively looking for work, such as disability, the number of children in the household, the presence of additional working-age household members, gender, age, and education (see Ntuli and Wittenberg 2013). Moreover, a $t$-test shows that the proportion of women in this category $(66 \%)$ is not significantly higher than in the rest of the sample $(63 \%$; $p$-value $=0.40)$.

Table 5 shows the frequencies of each labor market status. Only $29.6 \%$ of those at working age are economically active in the formal labor market. Over one-third of the population (34.4\%) at working age is not working but is actively looking for work. The 
corresponding unemployment rate of $51.8 \%$ of the economically active population is higher than the national average due to the high proportion of rural areas covered by the survey. The distributions of labor market outcomes in the different church categories in Figure 3 show that labor market performance differs substantially across the different churches.

Table 5. Frequencies of labor market outcomes and mean religiosity by labor market outcome.

\begin{tabular}{|c|c|c|c|c|}
\hline \multirow{2}{*}{ Labor Market Status } & \multirow{2}{*}{$N$} & \multirow{2}{*}{ Percentage } & \multicolumn{2}{|c|}{ CRS } \\
\hline & & & Mean & SD \\
\hline $3=($ self-)employed formal labor market & 321 & 29.56 & 4.16 & 0.70 \\
\hline $2=($ self-)employed informal labor market & 203 & 18.69 & 4.06 & 0.75 \\
\hline $1=$ not working and actively looking for work & 373 & 34.35 & 3.98 & 0.72 \\
\hline $0=$ not working and not actively looking for work & 189 & 17.40 & 3.87 & 0.85 \\
\hline
\end{tabular}

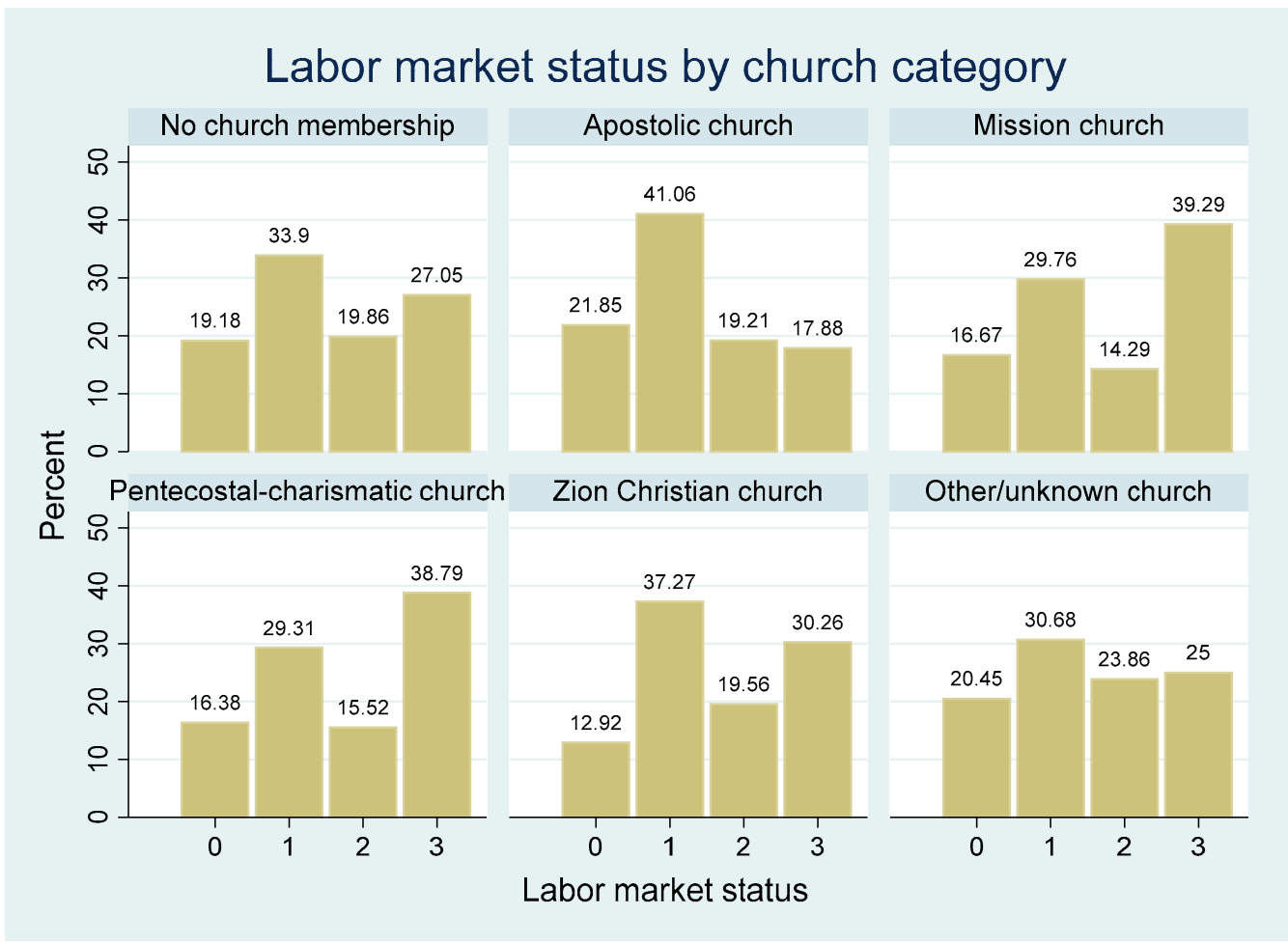

Figure 3. Labor market status by church membership. Note-Figure shows the distribution of labor market status according to church category. Labor market status 0 indicates not working and not actively looking for work, 1 indicates not working but actively looking for work, 2 indicates employment or self-employment in the informal sector, 3 indicates formal sector employment or self-employment.

\section{Estimation Strategy and Identification}

\subsection{Estimation Strategy}

The main econometric approach is the estimation of ordered probit and instrumental variable ordered probit models (the following description follows Wooldridge (2010)). I use the ordered probit model due to the ordinal nature of the dependent variable, Labor. It 
can take outcome values from 0 to 3 , indicating different labor market statuses (Table 5). ${ }^{7}$ Covariates include sociodemographic characteristics at the individual and household levels, migration, education, and social capital, as listed in Table 1 (Panel I). Furthermore, I control for household composition and social grant receipt, as these factors affect household labor market supply (Ardington et al. 2009).

For the ordered probit approach, a latent continuous variable Labor ${ }^{*}$ is defined:

$$
\operatorname{Labor}_{i}^{*}=x_{i} \beta+e_{i}
$$

where $x_{i}$ is a $1 \times K$ a vector of the explanatory variables, $\beta(K \times 1)$ denotes the vector of the respective estimation coefficients, and $e_{i}$ is the error term $\left(e_{i} \sim N(0,1)\right)$. Subscript $i$ denotes the individual. Explanatory variables include sociodemographic characteristics at the individual and household levels, education, social capital, migration, language, and ward indicators. To examine whether religion is a factor influencing these outcomes, $\boldsymbol{x}_{i}$ includes a set of proxies for different theological tenets and religious intensity. Indicator variables for membership in different church denominations stand for a specific set of beliefs and so does the indicator for the practice of African traditional religion. The Centrality of Religiosity Scale (see Section 4) constitutes an index of individual religiosity independent of specific tenets. Labor assumes the value of $0,1,2$, and 3 depending on the value of Labor* according to unknown cut points $\alpha_{j}$ (with $j=1,2,3$ ):

$$
\text { Labor }_{i}= \begin{cases}0 & \text { if Labor } \text { L }_{i}^{*} \leq \alpha_{1} \\ 1 & \text { if } \alpha_{1}<\text { Labor }_{i}^{*} \leq \alpha_{2} \\ 2 & \text { if } \alpha_{2}<\text { Labor }_{i}^{*} \leq \alpha_{3} \\ 3 & \text { if } \text { Labor }_{i}^{*}>\alpha_{3}\end{cases}
$$

The cut points are estimated in the model. The response probability of each outcome of Labor is the probability that the value of the latent variable Labor ${ }^{*}$ is between the respective cut points. The probabilities are as follows:

$$
\begin{aligned}
& \operatorname{Pr}\left(\text { Labor }_{i}=0 \mid \boldsymbol{x}_{i}\right)=\Phi\left(\alpha_{1}-\boldsymbol{x}_{i} \boldsymbol{\beta}\right) \\
& \operatorname{Pr}\left(\text { Labor }_{i}=1 \mid \boldsymbol{x}_{i}\right)=\Phi\left(\alpha_{2}-\boldsymbol{x}_{i} \boldsymbol{\beta}\right)-\Phi\left(\alpha_{1}-\boldsymbol{x}_{i} \boldsymbol{\beta}\right) \\
& \operatorname{Pr}\left(\text { Labor }_{i}=2 \mid \boldsymbol{x}_{i}\right)=\Phi\left(\alpha_{3}-\boldsymbol{x}_{i} \boldsymbol{\beta}\right)-\Phi\left(\alpha_{2}-\boldsymbol{x}_{i} \boldsymbol{\beta}\right) \\
& \operatorname{Pr}\left(\text { Labor }_{i}=3 \mid \boldsymbol{x}_{i}\right)=1-\Phi\left(\alpha_{3}-\boldsymbol{x}_{i} \boldsymbol{\beta}\right)
\end{aligned}
$$

where $\Phi$ is the cumulative distribution function. Maximum likelihood estimation is used to estimate the model.

The model described above assumes that all explanatory variables are exogenous. However, $C R S$ can be expected to be endogenous (i.e., $\operatorname{Cov}\left(r_{i}, e_{i}\right) \neq 0$, where $r_{i}$ denotes CRS). As the individuals self-select into religion and religious practice, it is likely that there is a bias due to omitted variables and simultaneous equations. Unobserved factors might influence individual religiosity and labor market performance, or the causality might run from labor market performance to religiosity. If $C R S$ is endogenous, this leads to biased estimates of the coefficients in Equation (1). To account for this endogeneity, I estimate justidentified instrumental variable ordered probit models (Roodman 2011; Wooldridge 2010). The index model in Equation (1) is reformulated to the following:

$$
\operatorname{Labor}_{i}^{*}=\boldsymbol{x}_{i} \boldsymbol{\beta}+\gamma C R S_{i}+u_{i}
$$

\footnotetext{
An alternative approach would be to use linear models. The ordinary least squares and two-state least squares models would have the advantage of more intuitive coefficient interpretation. Moreover, various test statistics exist to assess identification strength in the linear instrumental variable settings, which have not yet been developed for instrumental variable ordered probit estimation. The disadvantage would be that the categorical nature of Labor could not be considered, as these models assume a continuous outcome. Acknowledging that there are good arguments for the use of either model, I present the ordered probit methodology and results in the main paper and equivalent linear estimations in Appendix A. Both lead to similar results.
} 
where $x_{i}$ is the $(1 \times(K-1))$ vector of exogenous explanatory variables (excluding CRS) and $\beta((K-1) \times 1)$ is the coefficient vector. The coefficient of the endogenous variable $C R S$ is denoted by $\gamma$.

The reduced form equation for $C R S$ is as follows:

$$
C R S_{i}=x_{i} \delta+\theta z_{i}+v_{i}
$$

where $\delta$ is the $(K-1) \times 1$ vector of coefficients in the reduced form, $z_{i}$ denotes the instrumental variable, and $\theta$ is its coefficient. The error terms $u_{i}$ and $v_{i}$ are assumed to follow a joint normal distribution $\left(u_{i}, v_{i} \sim N(0, \Sigma)\right)$. The model is estimated using maximum likelihood estimation using the extended ordered probit (eoprobit) routine in Stata 15.

The identifying conditions of the model are as follows:

$$
\begin{gathered}
\theta \neq 0 \text { (relevance) } \\
\operatorname{Cov}\left(z_{i}, u_{i}\right)=0 \text { (validity) }
\end{gathered}
$$

The relevance condition in Expression (6) states that the instrumental variable $z_{i}$ must be partially correlated with $r_{i}$ conditional on all other explanatory variables. The condition can be statistically tested by testing the significance of the coefficient in the reduced form. The validity condition in Equation (7) implies that the instrument is unrelated to Labor except through its partial correlation with $C R S$ and can hence be excluded from the outcome equation (Equation (4)). This condition cannot be directly tested.

\subsection{Contingency Experience as an Instrumental Variable for "Treatment" with Religion}

When investigating potential causal mechanisms with respect to the effects of religion, the challenge is to find a variable fulfilling the two identifying conditions. Drawing on works by Luhmann (1982), Lübbe (2004), and Norris and Inglehart (2011), I identify the experience of contingency as an instrument for "treatment" with religion. Contingency experience (Luhmann 1982) refers to experiences of "existential insecurity" (Norris and Inglehart 2011). Such insecurities can, for example, be produced by a death in the family, illness, natural disasters, or other unpredictable events affecting one's life. Religion provides a means of dealing with these existential insecurities, risk, and unpredictable events in a process of "religious coping" (Ano and Vasconcelles 2005; Pargament 1997, 2012). "Religions provide existential reassurance to people who live in conditions of extreme vulnerability and uncertainty" (Silver 2006) and, as the review by Ano and Vasconcelles (2005) shows, "religious coping strategies are significantly associated with psychological adjustment to stress". Consequently, individual religiosity would increase with the contingencies a person experiences. Such an increase in religiosity might, for example, become measurable in the CRS' dimensions of private practice (increased prayer frequency), public practice (increased religious service attendance), or the intellectual dimension (increased frequency of thinking about religious issues). Recent empirical studies demonstrate that contingency experiences have an effect on religiosity. In her recent article, Bentzen (2019) showed that the occurrence of earthquakes in geographic proximity increases individuals' intrinsic religiosity. The study is based on individual data from 96 countries (including South Africa) and the results are consistent with the notion that religion is used as a mechanism to cope with the occurrence of unpredictable natural disasters. "Adversity, caused by natural disasters," as Bentzen argues, "instigates people across the globe to use their religion more intensively" (Bentzen 2020). In a similar vein, the same author shows that religiosity globally increased in the COVID-19 pandemic, based on an assessment of the number of Google searches for prayer (Bentzen 2020) - indicating an increase in the dimension of private practice. The study on Canada by Zapata (2018) shows that "among religious individuals, human losses increase the intensity of their religious preferences". The author concludes that "religion provides people ... with a mechanism to deal with adverse experiences resulting from climate disasters." These studies are in 
line with Norris and Inglehart's (2011) hypothesis that religiosity is higher in contexts of existential insecurity.

However, the relationship of contingency experience and religiosity is likely more complex. Individual religiosity is not only determined by a single factor. It is influenced by a wide range of social and cultural factors as well as highly dependent on the individual's religious socialization, experiences, personal traits, age, etc. (for overviews, see Aleksynska and Chiswick 2013; Saroglou 2021). Regarding the mechanisms described in the studies on religious coping, a relevant question seems to be whether an individual already has a level of religiosity or religious socialization. Bentzen (2020) found no effect of the COVID-19 pandemic on the number of prayer-related Google searches for the decile of those countries that are least religious. Similarly, Zapata's (2018) findings support the hypothesis that natural disasters lead to increased religiosity among the religious and further erode religious beliefs among the less religious. As Pargament (2012) points out, "a number of studies have shown that people are more likely to involve religion in coping when religion is a larger part of their orienting system", i.e., in contexts marked by high levels of religiosity and the prevalence of spiritual and religious worldviews. "People draw on religious solutions to problems from a more general orienting system that is made up of well-established beliefs, practices, attitudes, goals and values" (Pargament and Raiya 2007), i.e., a prerequisite for religious coping is that people can access a religious belief system. Moreover, the religious and cultural context has an important influence on the levels of individual religiosity (Aleksynska and Chiswick 2013; Pargament 2012) and should therefore be taken into account in empirical studies. ${ }^{8}$

As outlined in Section 3, the South African context is highly religious. Religious and spiritual worldviews, belief systems, and practices constitute important aspects of people's lives. Considering the studies cited above, which show increases in religiosity induced by contingency experience for people who are already religious, there are hence good reasons to assume that, in South Africa, contingency experiences will have a positive effect on religiosity. Moreover, studies have highlighted both the role of religion in coping with adversities (see, for example, Masondo 2013; Oosthuizen 1988) as well as increases in specific forms of religiosity because of existential insecurities (see, for example, Ashforth 2005). This also emerged from the qualitative pre-study: the role of comprehensive spiritual "healing" - essentially the notion of dealing with adversities and insecurity through religious means-featured prominently both in focus group discussions and key informant interviews. Looking at the data at hand in this respect, we find a robust positive relationship of contingency experience and religiosity, as expected (Table 4). All dimensions of the index of contingency experience are positively correlated with the CRS. I therefore proceed to assume contingency to be an exogenous factor that leads to increases in religiosity as measured in the CRS.

I exploit the positive relationship of contingency experience and religiosity in the data using two indicators of contingency experience introduced in Section 4, Contingency experience and Experience of death. With respect to Contingency experience, the first three questions on situations of fundamental despair/joy and unexplainable situations might be argued to include, at least partially, an interpretation on the part of the respondent. Respondents might classify a situation as being of fundamental despair/joy or as being unexplainable on the basis of their religious background. If religiosity influenced the answers to the contingency questions, this would constitute an endogeneity problem in the reduced form and violate the exclusion restriction (7). While this can be considered unlikely, I hedge against this possibility by using the second indicator of contingency,

8 Psychological literature also points to the fact that the role of religion in coping with adversity can be both positive and negative. While it can be helpful in coping with contingency experiences, it can also be harmful by exacerbating the experience. Pargament (2012) points to "religious struggles" caused by stressful events such as contingency experiences. However, the question of whether religion has positive or negative effects for the coping process is not relevant for the argument presented here, as the crucial point is that the contingency experience triggers a religious response. Even a religious struggle produced by contingency experience shows that these experiences affect the individual's religiosity. A religious struggle might lead to increases in intellectual dimension or the dimension of private practice. 
Experience of death, which can hardly be argued to be driven by religious interpretation. Moreover, previous research suggests that experience of death constitutes a contingency experience that can contribute to increased religiosity (as, for example, shown by Zapata 2018) and that religion is used to cope with experiences of death in close social proximity (Ungureanu and Sandberg 2010). In Section 6.2, I scrutinize the validity of the exclusion restriction for our case by evaluating potential alternative pathways from contingency experience to labor market performance in the data.

\subsection{Controlling for Endogeneity of Church Membership and African Traditional Religion}

In addition to the endogeneity of religiosity, I also control for the endogeneity of church membership and African traditional religious practice. In addition, in the cases of these variables, issues of self-selection, omitted variables, and simultaneous equations might cause endogeneity problems. Hence, the econometric model outlined above is extended by including the indicators Church and African traditional as endogenous regressors. As instrumental variables I use the share of persons per ward who are church members (Share church) or practice African traditional religion (Share Afr. traditional), respectively. ${ }^{9}$ The identifying condition (6) implies that the share of persons who are church members (or the share of persons practicing African traditional religion, respectively) is a good predictor of individual church membership (or African traditional religious practice, respectively). The validity condition (7) implies that the respective shares of church members and persons practicing African traditional religion do not affect individual income (except through a partial correlation with individual membership/practice). Whether or not the validity condition holds when using the shares of affiliation as instruments can be disputed. However, I do not make causal claims with respect to the church membership and African traditional religious practice but rather use them as controls to assess the robustness of the effect estimates of religiosity.

Accounting for the endogeneity of all three variables, CRS, Church, and African traditional, the above model becomes the following:

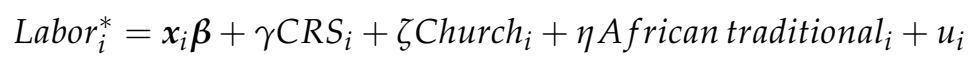

where $x_{i}$ is a vector of exogenous covariates, and $\beta$ is the coefficient vector. The estimation coefficients of the endogenous variables CRS, Church, and African traditional are denoted $\gamma$, $\zeta$, and $\eta$, respectively. The first-stage equations are as follows:

$$
\begin{gathered}
C R S_{i}=x_{i} \delta_{r}+\theta_{r 1} z_{1 i}+\theta_{r 2} z_{2 i}+\theta_{r 3} z_{3 i}+v_{r i} \\
\text { Church }_{i}=x_{i} \delta_{c}+\theta_{c 1} z_{1 i}+\theta_{c 2} z_{2 i}+\theta_{c 3} z_{3 i}+v_{c i} \\
\text { African traditional }{ }_{i}=x_{i} \delta_{a}+\theta_{a 1} z_{1 i}+\theta_{a 2} z_{2 i}+\theta_{a 3} z_{3 i}+v_{a i}
\end{gathered}
$$

where $\delta_{r}, \delta_{c}$, and $\delta_{a}$ are vectors of coefficients in the first-stage estimations, and $z_{1 i}, z_{2 i}$, and $z_{3 i}$ denote the instrumental variables. In addition, $\theta_{r 1}, \theta_{r 2}$, and $\theta_{r 3}$ are the first-stage effects of the instruments on $C R S$, while $\theta_{c 1}, \theta_{c 2}$, and $\theta_{c 3}$ are the first-stage effects of the instruments on Church, and $\theta_{a 1}, \theta_{a 2}$, and $\theta_{a 3}$ are the first-stage effects of the instruments on African traditional. The error terms in the first stages are denoted $v_{r i}, v_{c i}$, and $v_{a i}$. The model is also estimated using maximum likelihood estimation using the eoprobit routine in Stata 15.

\section{Results}

\subsection{Estimation Results}

In Table 6, columns (1) to (5) display ordered probit estimation results of the ordinal scale of labor market outcomes (Labor) using varying sets of explanatory variables for religious affiliation and religiosity. Column (1) uses a single indicator of church membership

9 A similar approach is used by Beck and Gundersen (2016) in their study on religion and income in Ghana. 
along with an indicator of African traditional religion. Church membership does not have a significant coefficient, and the coefficient of African traditional religion is only weakly significant. Column (2) shows the results using differentiated church membership indicators instead of a single indicator for membership in any church. The different signs and magnitudes of the coefficients suggest heterogeneity in the relationship of church affiliation and labor market performance. Only two of the church category coefficients are significant, Pentecostal-Charismatic church (at the 10\% level) and Zion Christian church (at the 5\% level); the coefficient of African traditional is now significant at the 5\% level. Columns (3) and (4) present the results of Models (1) and (2), when adding individual religiosity, as captured by the Centrality of Religiosity Scale in the variable CRS. The coefficient of church decreases nearly ten-fold when comparing Models (3) to (1), while the coefficient of African traditional increases slightly. This pattern is similar in the comparison of Models (4) and (2). African traditional religion's coefficient has a similar magnitude as in Model (2), while the church category coefficients differ substantially. The size of the coefficients of Pentecostal-Charismatic church and Zion Christian church decreases by around $50 \%$, and neither remains statistically significant. The coefficient displaying the largest absolute value is that of Apostolic church. It is negative but not significant. The coefficient of CRS is significant at the $5 \%$ level in both Models (3) and (4). From these results, we can highlight the following preliminary findings. First, religion is positively associated with labor market performance. Second, church membership per se is not related to better labor market performance; the association rather seems to be heterogeneous across church categories. Third, individual religiosity is a better predictor of labor market performance than membership in different churches. What seems to matter in the relationship of religion and labor market performance is not the membership in a specific church, but the intensity of belief regardless of its specific theological content. The OLS estimation results of the same models displayed in Table A1 in Appendix A confirm the general picture.

Table 7 displays instrumental variable ordered probit estimates, accounting for the potential endogeneity of religion. CRS has coefficients significant at least at the $5 \%$ level in all five specifications. Models (1) and (2) correspond to Model (5) in Table 6. They only include one variable relating to religion, CRS. In Model (1), it is instrumented with Contingency experience, and in Model (2), it is instrumented with Experience of death to hedge against potential endogeneity of self-reported contingency experiences in the first stage. In both cases, the coefficient of $C R S$ remains significant at the $1 \%$ level, and the magnitude of the coefficient increased around seven-fold (to 0.742 and 0.772 ) compared to the non-instrumented estimates in Table 6.

Models (3) to (5) additionally include the variables Church and African traditional. They are instrumented with the respective share of church members and adherents of African traditional religion in the ward. CRS continues to have a significant coefficient, while none of the coefficients of Church and African traditional shows a significant effect. In Model (3), which instruments $C R S$ with Contingency experience, the coefficient is 0.775 , a very similar magnitude as in Models (1) and (2), and significant at the $1 \%$ level. In Model (4), in which the instrument is Experience of death, the coefficient increases to 0.910. The fact that the Experience of death is only weakly significant in the first stage might highlight weak instrument issues in this estimation. Model (5) provides a robustness check using a different instrument for CRS. Similar to the instruments included for Church and African traditional, $C R S$ is instrumented with its average value in the ward. The coefficient is around one-third smaller (0.430), but still around four times the size of the non-instrumented estimates in Table 6 and significant at the $5 \%$ level. 
Table 6. Estimation results ordered probit model.

\begin{tabular}{|c|c|c|c|c|c|}
\hline & (1) & (2) & (3) & (4) & (5) \\
\hline CRS (std.ized) & & & $\begin{array}{c}0.110^{* *} \\
(0.044)\end{array}$ & $\begin{array}{c}0.110^{* *} \\
(0.044)\end{array}$ & $\begin{array}{c}0.108^{* * *} \\
(0.039)\end{array}$ \\
\hline African traditional & $\begin{array}{l}0.117^{*} \\
(0.070)\end{array}$ & $\begin{array}{c}0.151^{* *} \\
(0.071)\end{array}$ & $\begin{array}{l}0.124^{*} \\
(0.070)\end{array}$ & $\begin{array}{c}0.154^{* *} \\
(0.071)\end{array}$ & \\
\hline Church & $\begin{array}{l}0.143 * \\
(0.085)\end{array}$ & & $\begin{array}{c}0.017 \\
(0.094)\end{array}$ & & \\
\hline Apostolic church & & $\begin{array}{l}-0.065 \\
(0.110)\end{array}$ & & $\begin{array}{l}-0.189 \\
(0.118)\end{array}$ & \\
\hline Mission church & & $\begin{array}{c}0.186 \\
(0.131)\end{array}$ & & $\begin{array}{c}0.086 \\
(0.133)\end{array}$ & \\
\hline Pent.-Charismatic church & & $\begin{array}{l}0.282 * \\
(0.151)\end{array}$ & & $\begin{array}{c}0.128 \\
(0.159)\end{array}$ & \\
\hline Zion Christian church & & $\begin{array}{c}0.234^{* *} \\
(0.100)\end{array}$ & & $\begin{array}{c}0.106 \\
(0.109) \\
\end{array}$ & \\
\hline Other church & & $\begin{array}{c}0.056 \\
(0.147)\end{array}$ & & $\begin{array}{l}-0.084 \\
(0.158)\end{array}$ & \\
\hline Ward indicators & Yes & Yes & Yes & Yes & Yes \\
\hline Covariates & Yes & Yes & Yes & Yes & Yes \\
\hline$\chi^{2}$ & 274.73 & 291.55 & 274.51 & 291.04 & 265.92 \\
\hline
\end{tabular}

Note-Dependent variable: employment status $(0=$ not looking for work, $1=$ actively looking for work, $2=$ employed in informal sector, $3=$ employed in formal sector); covariates include sociodemographic characteristics at individual and household levels, education, social capital, migration, language, and social security grant receipt (see Table 1, Panel I); cut-offs omitted; standard errors in parentheses clustered at the household level; $N=1086 ;{ }^{*} p<0.1{ }^{* *} p<0.05,{ }^{* * *} p<0.01$

Table 7. Estimation results instrumental variable ordered probit model.

\begin{tabular}{|c|c|c|c|c|c|}
\hline & (1) & (2) & (3) & (4) & (5) \\
\hline CRS (std.ized) & $\begin{array}{l}0.742 * * * \\
(0.125)\end{array}$ & $\begin{array}{c}0.772 * * * \\
(0.237)\end{array}$ & $\begin{array}{l}0.775^{* * *} \\
(0.135)\end{array}$ & $\begin{array}{l}0.910 * * * \\
(0.211)\end{array}$ & $\begin{array}{l}0.430 * * \\
(0.206)\end{array}$ \\
\hline African traditional & & & $\begin{array}{l}-0.430 \\
(0.304)\end{array}$ & $\begin{array}{l}-0.321 \\
(0.286)\end{array}$ & $\begin{array}{l}-0.329 \\
(0.421)\end{array}$ \\
\hline Church & & & $\begin{array}{l}-0.127 \\
(0.589)\end{array}$ & $\begin{array}{l}-0.019 \\
(0.468)\end{array}$ & $\begin{array}{l}-0.496 \\
(0.618)\end{array}$ \\
\hline Ward indicators & Yes & Yes & No & No & No \\
\hline Covariates & Yes & Yes & Yes & Yes & Yes \\
\hline $\begin{array}{c}\text { First stages: } \\
\text { CRS (std.ized) } \\
\text { Contingency experience }\end{array}$ & $\begin{array}{l}0.704^{* * *} \\
(0.136)\end{array}$ & & $\begin{array}{l}0.641^{* * *} \\
(0.125)\end{array}$ & & \\
\hline Experience of death & & $\begin{array}{l}0.235^{* * *} \\
(0.088)\end{array}$ & & $\begin{array}{l}0.142 * \\
(0.082)\end{array}$ & \\
\hline Mean CRS (std.ized) & & & & & $\begin{array}{c}0.192^{* * *} \\
(0.028)\end{array}$ \\
\hline $\begin{array}{c}\text { Church } \\
\text { Share church (std.ized) }\end{array}$ & & & $\begin{array}{c}0.047^{* * *} \\
(0.012)\end{array}$ & $\begin{array}{l}0.045^{* * *} \\
(0.013)\end{array}$ & $\begin{array}{c}0.065^{* * * *} \\
(0.013)\end{array}$ \\
\hline $\begin{array}{l}\text { African traditional } \\
\text { Share Afr. trad. (std.ized) }\end{array}$ & & & $\begin{array}{c}0.094^{* * *} \\
(0.016)\end{array}$ & $\begin{array}{c}0.094^{* * *} \\
(0.016)\end{array}$ & $\begin{array}{c}0.096^{* * * *} \\
(0.016)\end{array}$ \\
\hline$x^{2}$ & 454.940 & 467.288 & 503.482 & 782.955 & 269.573 \\
\hline
\end{tabular}

Note-Dependent variable: employment status $(0=$ not looking for work, $1=$ actively looking for work, $2=$ employed in informal sector, $3=$ employed in formal sector); covariates include sociodemographic characteristics at individual and household levels, education, social capital, migration, language, and social security grant receipt (see Table 1, Panel I); cut-offs omitted; standard errors in parentheses clustered at the household level; each first stage includes the full set of covariates; $N=1086 ;{ }^{*} p<0.1,{ }^{* *} p<0.05,{ }^{* * *} p<0.01$. 
With respect to the instruments' relevance, the first-stage estimates show that both Contingency experience and Experience of death instruments are positively correlated with $C R S$ and have significant explanatory power. The coefficient of Contingency experience is significant at the 1\% level and the coefficient of Experience of death at the 5\% level. Having had all four contingency experiences increases religiosity by between $64.1 \%$ and $70.4 \%$ of a standard deviation, while an experience of death in close social proximity increases religiosity by between $14.2 \%$ and $23.5 \%$ of a standard deviation. The shares of church members and of persons practicing African traditional religion are good predictors of Church and African traditional. An increase in the share of church members in the ward by one standard deviation increases the probability of being a church member by between 4.5 and 6.5 percentage points, while an increase in the share of adherents of African traditional religion increases the probability of practicing African traditional religion by between 9.4 and 9.6 percentage points. The first-stage coefficient of Mean CRS in Model (5) shows mean religiosity in the ward to be a relevant instrument for religiosity as well. An increase in Mean CRS by one standard deviation is associated with an increase in CRS by $19.2 \%$ of a standard deviation.

Regarding the magnitude of the effects of CRS on Labor, I estimate the average marginal effects for the coefficients in Tables 6 and 7. The estimates are found in Tables 8 and 9, respectively. In the naïve model without accounting for endogeneity (Tables 6 and 8), an increase in a standard deviation in CRS decreases the probability of not working and not actively looking for work $($ Labor $=0)$ by 2.4 percentage points. At the same time, it increases the probability of being in formal employment (Labor $=3$ ) by 3.2 percentage points. The figures for the instrumental variable models are substantially higher (displayed in Table 9). Those models instrumenting CRS with Contingency experience (Models (1) to (3)) show the probability of not working and not actively seeking work $($ Labor $=0)$ to decrease by between 20.8 and 24.0 percentage points, to decrease the probability of actively looking for work $($ Labor $=1)$ by 11.2 to 13.2 percentage points, to increase the probability of informal employment $($ Labor $=2)$ by 4.4 to 5.1 percentage points, and to increase the probability of formal employment $($ Labor $=3)$ by between 27.6 and 32.1 percentage points. The respective average marginal effect coefficients for Model (4), which uses Experience of death as instrument, have the same signs and are around one-third larger in absolute terms. When using mean religiosity (the mean value of the CRS) in the ward as an instrument (Model (5)), the signs are also the same, but the coefficients are around half the size as in Models (1) to (3). Assuming that Models (4) and (5) constitute upper and lower bounds of the true estimate, it seems that the true effect of $C R S$ is in the region of magnitude shown for the coefficients in Models (1) to (3).

The instrumental variable estimates confirm that religiosity has a substantial positive effect on labor market performance. Considering the large size of the instrumental variable coefficients compared to the non-instrumented versions both in the ordered probit and the OLS estimations, it is worthwhile noting that the instrumental variable estimates are not representative for the whole population but constitute local average treatment effects. They describe the effect of religiosity on labor market performance for those whose "treatment" (religiosity) was altered by experiences of contingency. 
Table 8. Average marginal effect estimates for Table 6.

\begin{tabular}{|c|c|c|c|c|c|c|c|c|c|c|c|c|}
\hline & \multicolumn{4}{|c|}{$\begin{array}{c}\text { (1a) } \\
\text { Outcome Labor }\end{array}$} & \multicolumn{4}{|c|}{$\begin{array}{c}\text { (2a) } \\
\text { Outcome Labor }\end{array}$} & \multicolumn{4}{|c|}{$\begin{array}{c}\text { (3a) } \\
\text { Outcome Labor }\end{array}$} \\
\hline & 0 & 1 & 2 & 3 & 0 & 1 & 2 & 3 & 0 & 1 & 2 & 3 \\
\hline CRS (std.ized) & & & & & & & & & $\begin{array}{c}-0.024^{* *} \\
(0.010)\end{array}$ & $\begin{array}{c}-0.013^{* *} \\
(0.005)\end{array}$ & $\begin{array}{c}0.005^{* *} \\
(0.002)\end{array}$ & $\begin{array}{l}0.032 * * \\
(0.013)\end{array}$ \\
\hline African traditional & $\begin{array}{c}-0.026^{*} \\
(0.016)\end{array}$ & $\begin{array}{c}-0.014 * \\
(0.008)\end{array}$ & $\begin{array}{l}0.006^{*} \\
(0.003)\end{array}$ & $\begin{array}{l}0.034^{*} \\
(0.020)\end{array}$ & $\begin{array}{c}-0.034^{* *} \\
(0.016)\end{array}$ & $\begin{array}{c}-0.018 \text { ** } \\
(0.008)\end{array}$ & $\begin{array}{c}0.007^{* *} \\
(0.003)\end{array}$ & $\begin{array}{c}0.044^{* *} \\
(0.021)\end{array}$ & $\begin{array}{c}-0.028 * \\
(0.015)\end{array}$ & $\begin{array}{c}-0.015^{*} \\
(0.008)\end{array}$ & $\begin{array}{l}0.006^{*} \\
(0.003)\end{array}$ & $\begin{array}{l}0.036^{*} \\
(0.020)\end{array}$ \\
\hline Church & $\begin{array}{c}-0.032 \text { * } \\
(0.019)\end{array}$ & $\begin{array}{c}-0.017^{*} \\
(0.010)\end{array}$ & $\begin{array}{c}0.007 \\
(0.004)\end{array}$ & $\begin{array}{l}0.042^{*} \\
(0.025)\end{array}$ & & & & & $\begin{array}{l}-0.004 \\
(0.021)\end{array}$ & $\begin{array}{l}-0.002 \\
(0.011)\end{array}$ & $\begin{array}{c}0.001 \\
(0.004)\end{array}$ & $\begin{array}{c}0.005 \\
(0.028)\end{array}$ \\
\hline Apostolic church & & & & & $\begin{array}{c}0.014 \\
(0.024) \\
\end{array}$ & $\begin{array}{c}0.008 \\
(0.013) \\
\end{array}$ & $\begin{array}{l}-0.003 \\
(0.005) \\
\end{array}$ & $\begin{array}{l}-0.019 \\
(0.032) \\
\end{array}$ & & & & \\
\hline Mission church & & & & & $\begin{array}{l}-0.041 \\
(0.029)\end{array}$ & $\begin{array}{l}-0.022 \\
(0.016)\end{array}$ & $\begin{array}{c}0.009 \\
(0.006)\end{array}$ & $\begin{array}{c}0.055 \\
(0.038)\end{array}$ & & & & \\
\hline Pent.-charism. church & & & & & $\begin{array}{c}-0.063 * \\
(0.033)\end{array}$ & $\begin{array}{c}-0.033 * \\
(0.018)\end{array}$ & $\begin{array}{l}0.013^{*} \\
(0.007)\end{array}$ & $\begin{array}{l}0.083 * \\
(0.044)\end{array}$ & & & & \\
\hline Zion Christian church & & & & & $\begin{array}{c}-0.052 * * \\
(0.022)\end{array}$ & $\begin{array}{c}-0.028 * * \\
(0.012)\end{array}$ & $\begin{array}{l}0.011^{* *} \\
(0.005)\end{array}$ & $\begin{array}{c}0.068^{* *} \\
(0.029)\end{array}$ & & & & \\
\hline \multirow[t]{3}{*}{ Other church } & & & & & $\begin{array}{l}-0.012 \\
(0.033)\end{array}$ & $\begin{array}{l}-0.007 \\
(0.017)\end{array}$ & $\begin{array}{c}0.003 \\
(0.007)\end{array}$ & $\begin{array}{c}0.016 \\
(0.043)\end{array}$ & & & & \\
\hline & \multicolumn{4}{|c|}{$\begin{array}{c}\text { (4a) } \\
\text { Outcome Labor }\end{array}$} & \multicolumn{4}{|c|}{$\begin{array}{c}(5 a) \\
\text { Outcome Labor }\end{array}$} & & & & \\
\hline & 0 & 1 & 2 & 3 & 0 & 1 & 2 & 3 & & & & \\
\hline CRS (std.ized) & $\begin{array}{c}-0.024^{* *} \\
(0.010)\end{array}$ & $\begin{array}{l}-0.013^{* *} \\
(0.005)\end{array}$ & $\begin{array}{l}0.005^{* *} \\
(0.002)\end{array}$ & $\begin{array}{l}0.032 * * \\
(0.013)\end{array}$ & $\begin{array}{c}-0.024^{* * * *} \\
(0.009)\end{array}$ & $\begin{array}{c}-0.013^{* * *} \\
(0.005)\end{array}$ & $\begin{array}{c}0.005^{* * *} \\
(0.002)\end{array}$ & $\begin{array}{c}0.032^{* * *} \\
(0.011)\end{array}$ & & & & \\
\hline African traditional & $\begin{array}{c}-0.034^{* *} \\
(0.016)\end{array}$ & $\begin{array}{l}-0.018^{* *} \\
(0.009)\end{array}$ & $\begin{array}{l}0.007^{* *} \\
(0.003)\end{array}$ & $\begin{array}{l}0.045^{* *} \\
(0.021)\end{array}$ & & & & & & & & \\
\hline Apostolic church & $\begin{array}{c}0.042 \\
(0.026)\end{array}$ & $\begin{array}{c}0.022 \\
(0.014)\end{array}$ & $\begin{array}{l}-0.009 \\
(0.005)\end{array}$ & $\begin{array}{l}-0.055 \\
(0.034)\end{array}$ & & & & & & & & \\
\hline Mission church & $\begin{array}{l}-0.019 \\
(0.029)\end{array}$ & $\begin{array}{l}-0.010 \\
(0.016)\end{array}$ & $\begin{array}{c}0.004 \\
(0.006)\end{array}$ & $\begin{array}{c}0.025 \\
(0.039)\end{array}$ & & & & & & & & \\
\hline Pent.-charism. church & $\begin{array}{l}-0.028 \\
(0.035) \\
\end{array}$ & $\begin{array}{l}-0.015 \\
(0.019) \\
\end{array}$ & $\begin{array}{c}0.006 \\
(0.007)\end{array}$ & $\begin{array}{c}0.037 \\
(0.046)\end{array}$ & & & & & & & & \\
\hline Zion Christian church & $\begin{array}{l}-0.023 \\
(0.024)\end{array}$ & $\begin{array}{l}-0.012 \\
(0.013)\end{array}$ & $\begin{array}{c}0.005 \\
(0.005)\end{array}$ & $\begin{array}{c}0.031 \\
(0.032)\end{array}$ & & & & & & & & \\
\hline Other church & $\begin{array}{c}0.018 \\
(0.035)\end{array}$ & $\begin{array}{c}0.010 \\
(0.019)\end{array}$ & $\begin{array}{l}-0.004 \\
(0.007)\end{array}$ & $\begin{array}{l}-0.024 \\
(0.046)\end{array}$ & & & & & & & & \\
\hline
\end{tabular}


Table 9. Average marginal effect estimates for Table 7.

\begin{tabular}{|c|c|c|c|c|c|c|c|c|c|c|c|c|}
\hline & \multicolumn{4}{|c|}{$\begin{array}{c}\text { (1a) } \\
\text { Outcome Labor }\end{array}$} & \multicolumn{4}{|c|}{$\begin{array}{c}(2 a) \\
\text { Outcome Labor }\end{array}$} & \multicolumn{4}{|c|}{$\begin{array}{c}\text { (3a) } \\
\text { Outcome Labor }\end{array}$} \\
\hline & 0 & 1 & 2 & 3 & 0 & 1 & 2 & 3 & 0 & 1 & 2 & 3 \\
\hline $\begin{array}{c}\text { CRS } \\
\text { (std.ized) }\end{array}$ & $\begin{array}{c}-0.208^{* * *} \\
(0.057)\end{array}$ & $\begin{array}{c}-0.112 * * * \\
(0.011)\end{array}$ & $\begin{array}{c}0.044^{* * *} \\
(0.006)\end{array}$ & $\begin{array}{c}0.276^{* * *} \\
(0.062)\end{array}$ & $\begin{array}{c}-0.224 * \\
(0.119)\end{array}$ & $\begin{array}{c}-0.120^{* * *} \\
(0.011)\end{array}$ & $\begin{array}{c}0.047^{* * *} \\
(0.007)\end{array}$ & $\begin{array}{l}0.296^{* *} \\
(0.126)\end{array}$ & $\begin{array}{c}-0.240^{* * *} \\
(0.064)\end{array}$ & $\begin{array}{c}-0.132 * * * \\
(0.025)\end{array}$ & $\begin{array}{c}0.051^{* * *} \\
(0.012)\end{array}$ & $\begin{array}{c}0.321^{* * *} \\
(0.069)\end{array}$ \\
\hline $\begin{array}{l}\text { African } \\
\text { traditional }\end{array}$ & & & & & & & & & $\begin{array}{c}0.133 \\
(0.099)\end{array}$ & $\begin{array}{c}0.073 \\
(0.054)\end{array}$ & $\begin{array}{l}-0.028 \\
(0.022)\end{array}$ & $\begin{array}{l}-0.178 \\
(0.129)\end{array}$ \\
\hline Church & & & & & & & & & $\begin{array}{c}0.039 \\
(0.180)\end{array}$ & $\begin{array}{c}0.022 \\
(0.102)\end{array}$ & $\begin{array}{l}-0.008 \\
(0.039)\end{array}$ & $\begin{array}{l}-0.053 \\
(0.243)\end{array}$ \\
\hline & \multicolumn{4}{|c|}{$\begin{array}{c}\text { (4a) } \\
\text { Outcome Labor }\end{array}$} & \multicolumn{4}{|c|}{$\begin{array}{c}(5 a) \\
\text { Outcome Labor }\end{array}$} & & & & \\
\hline & 0 & 1 & 2 & 3 & 0 & 1 & 2 & 3 & & & & \\
\hline $\begin{array}{c}\text { CRS } \\
\text { (std.ized) }\end{array}$ & $\begin{array}{l}-0.367 \\
(0.241)\end{array}$ & $\begin{array}{c}-0.200 \text { *** } \\
(0.077)\end{array}$ & $\begin{array}{l}0.077^{*} \\
(0.045)\end{array}$ & $\begin{array}{l}0.490^{* *} \\
(0.216)\end{array}$ & $\begin{array}{c}-0.103^{* *} \\
(0.051)\end{array}$ & $\begin{array}{c}-0.056^{* *} \\
(0.025)\end{array}$ & $\begin{array}{c}0.022 * * \\
(0.008)\end{array}$ & $\begin{array}{c}0.137^{* *} \\
(0.067)\end{array}$ & & & & \\
\hline $\begin{array}{l}\text { African } \\
\text { traditional }\end{array}$ & $\begin{array}{c}0.129 \\
(0.101)\end{array}$ & $\begin{array}{c}0.071 \\
(0.090)\end{array}$ & $\begin{array}{l}-0.027 \\
(0.040)\end{array}$ & $\begin{array}{l}-0.173 \\
(0.139)\end{array}$ & $\begin{array}{c}0.079 \\
(0.103)\end{array}$ & $\begin{array}{c}0.043 \\
(0.054)\end{array}$ & $\begin{array}{l}-0.017 \\
(0.022)\end{array}$ & $\begin{array}{l}-0.105 \\
(0.136)\end{array}$ & & & & \\
\hline Church & $\begin{array}{l}0.007 \\
(0.188)\end{array}$ & $\begin{array}{l}0.004 \\
(0.103)\end{array}$ & $\begin{array}{l}-0.002 \\
(0.040)\end{array}$ & $\begin{array}{l}-0.010 \\
(0.251)\end{array}$ & $\begin{array}{c}0.119 \\
(0.150)\end{array}$ & $\begin{array}{c}0.064 \\
(0.079)\end{array}$ & $\begin{array}{l}-0.025 \\
(0.031)\end{array}$ & $\begin{array}{l}-0.158 \\
(0.198)\end{array}$ & & & & \\
\hline
\end{tabular}




\subsection{Validity of the Instrument}

The instrumental variable approach is based on the identifying assumption (Equation (7)) that Contingency experience and Experience of death do not directly or via unobserved variables influence labor market performance. I consider it unlikely that the experiences forming part of the index of contingency experience directly affect labor market performance. To substantiate this assumption, this section provides an empirical assessment of different counter-hypotheses.

Alternative Hypothesis 1. Responses to the questionnaire items on contingency experiences were influenced by ex ante religiosity.

Religious respondents, for example, might be more likely to interpret events experienced as unexplainable, or the reported situations of incredible joy might include positive labor-market-related events, such as unexpected job offers. A similar argument would be that religion is actually the cause of contingency experiences, i.e., that religious practices produce experiences that are perceived as contingency experiences. This could, for example, be experiences of conversion, experience of the attendance of religious mega events, or anxieties caused by religious struggles (Pargament 2012; Szcześniak et al. 2020). This situation would pose an endogeneity problem in the first-stage regressions. To verify that this is not the case, all instrumental variable models are also estimated using only Experience of death as instrument. Ex ante religiosity is highly unlikely to affect reports on mortality in close social proximity. Even though identification in some of the instrumental variable models using the instrument Experience of death is weaker, the estimation results using this variable largely confirm the results of the estimations that use Contingency experience as instrument.

Alternative Hypothesis 2. Contingency experiences constitute external shocks that produce despair. They negatively influence the propensity to engage in labor market activity.

This hypothesis would imply that labor market status and contingency experience were negatively correlated. I document the correlation of contingency experience and labor market outcomes by regressing the ordinal scale of labor market outcomes, Labor, on the four contingency dimensions. The full set of covariates is included, but the variables related to religion are omitted. Table 10 displays the results. All four dimensions of the index of contingency experience are positively correlated with religiosity (as measured in CRS) and - through religiosity, as I argue - with labor market status. It might be conceivable that there is a short-term negative effect not observed in the cross-sectional data. However, if this is the case, the effect is offset by religious coping effects in the long run (i.e., a positive effect of religiosity on labor market status).

Alternative Hypothesis 3. Income is positively correlated with better health and decreased mortality. Hence, a higher labor market status affects responses on Experience of death because of a decreased number of deaths in the family.

This would again entail that labor market status and Experience of death were negatively correlated. As documented in Table 10, this is not the case.

Alternative Hypothesis 4. Experience of death indicates the death of the main bread winner in the household. It increases the propensity of labor market activity, particularly for women.

This hypothesis would imply that the experiences of death were particularly influenced by female respondents, who constitute $63 \%$ of the sample. Table 10 provides the correlations (conditional on the covariates) of Labor and the four dimensions of Contingency experience for the subsample of male and female respondents. The table shows that Experience of death and labor market status are not significantly correlated in the female 
subsample. The overall correlation is driven by the male subsample. Moreover, to rule out the possibility that similar types of household composition drive the results, controls for household composition are included in all regressions (Table 1, Panel I).

Table 10. Estimation results regressing labor market status on contingency experiences.

\begin{tabular}{|c|c|c|c|}
\hline & (1) & (2) & (3) \\
\hline & $\begin{array}{l}\text { Ordered Probit } \\
\text { (Full Sample) }\end{array}$ & $\begin{array}{c}\text { Ordered Probit } \\
\text { (Subsample Male) }\end{array}$ & $\begin{array}{c}\text { Ordered Probit } \\
\text { (Subsample Female) }\end{array}$ \\
\hline (A) Despair & $\begin{array}{c}0.097 \\
(0.087)\end{array}$ & $\begin{array}{c}0.187 \\
(0.146)\end{array}$ & $\begin{array}{c}0.001 \\
(0.112)\end{array}$ \\
\hline (B) Joy & $\begin{array}{c}0.297 * * * \\
(0.101)\end{array}$ & $\begin{array}{c}0.541^{* * *} \\
(0.210)\end{array}$ & $\begin{array}{l}0.199 * \\
(0.115)\end{array}$ \\
\hline $\begin{array}{l}\text { (C) Unexplainable } \\
\text { events }\end{array}$ & $\begin{array}{l}0.158^{* *} \\
(0.073)\end{array}$ & $\begin{array}{c}0.109 \\
(0.125)\end{array}$ & $\begin{array}{l}0.185^{* *} \\
(0.094)\end{array}$ \\
\hline $\begin{array}{c}\text { (D) Experience of } \\
\text { death }\end{array}$ & $\begin{array}{l}0.191 * \\
(0.107)\end{array}$ & $\begin{array}{l}0.416^{* *} \\
(0.189)\end{array}$ & $\begin{array}{c}0.120 \\
(0.138)\end{array}$ \\
\hline $\begin{array}{c}\text { Ward indicators } \\
\text { Covariates }\end{array}$ & $\begin{array}{l}\text { Yes } \\
\text { Yes }\end{array}$ & $\begin{array}{l}\text { Yes } \\
\text { Yes }\end{array}$ & $\begin{array}{l}\text { Yes } \\
\text { Yes }\end{array}$ \\
\hline $\begin{array}{c}\text { Observations } \\
\chi^{2}\end{array}$ & $\begin{array}{c}1086 \\
287.95\end{array}$ & $\begin{array}{c}398 \\
200.54\end{array}$ & $\begin{array}{c}688 \\
152.85\end{array}$ \\
\hline 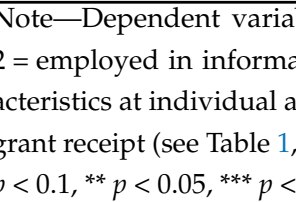 & $\begin{array}{l}\text { nployment status } \\
\text { r, } 3 \text { = employed in } \\
\text { isehold levels, educ } \\
\text { I); cut-offs omitted; }\end{array}$ & $\begin{array}{l}\text { looking for work, } 1 \\
1 \text { sector); covariates inc } \\
\text { social capital, migration } \\
\text { rd errors in parentheses }\end{array}$ & $\begin{array}{l}\text { actively looking for work } \\
\text { de sociodemographic char } \\
\text { nguage, and social security } \\
\text { stered at household level; }\end{array}$ \\
\hline
\end{tabular}

\section{Discussion}

The findings of this study show that individual religious intensity is more relevant in improving labor market performance than religious content (insofar as it can be proxied by religious affiliation). More specifically, I find that individual religiosity has a significant and substantial positive effect on different indicators of labor market performance. The general positive effect of individual religiosity on labor market performance is robust across a set of different specifications - even when including differentiated, context-relevant indicators of church membership and when restricting the analysis to subgroups of people not affiliated with any church and not practicing African traditional religion. Consequently, I conclude that religious affiliation itself does not affect labor market performance. As soon as religiosity is controlled for, any effect of membership in different churches disappears. Interestingly, the results point towards a positive relationship between the practice of African traditional religion and labor market performance even when controlling for religiosity-although, in this study, we cannot ascertain whether there are causal effects of African traditional religion on labor market performance.

The findings of this study point in a similar direction as the studies by Arano and Blair (2008), who identified religious intensity as the key factor related to higher income, and Bryan et al. (2021), who identified a causal link between the specifically religious components of a training program and income via increased individual religiosity. Furthermore, the results presented here resonate with the findings of two previous studies on the Ghanaian and South African contexts. Beck and Gundersen (2016) and Öhlmann and Hüttel (2018) show positive effects on household income of membership in African Independent and Pentecostal-Charismatic churches. As they do not specifically account for religious intensity, the effect of individual religiosity is likely to be absorbed by the membership variables, particularly as average levels of religiosity must be assumed to differ across the 
categories (as shown in our data). I conjecture that including religiosity in the analyses of Beck and Gundersen (2016) and Öhlmann and Hüttel (2018) might well lead to similar results as in this study. Scrutinizing this hypothesis empirically would be an interesting follow-up.

With respect to the literature on African Independent and Pentecostal-Charismatic churches, the results confirm that these churches foster an intensive religiosity, but reject the hypotheses stating that these churches particularly contribute to their members' labor market performance (Dickow 2012; Heuser 2013; Mafuta 2010; Meyer 2004; Schlemmer 2008). The findings suggest that it is not specific tenets in these churches that foster labor market performance but religious intensity. Nonetheless, average levels of religiosity differ according to church categories and are highest in Pentecostal-Charismatic churches-a finding consistent with the literature on these churches (e.g., Freeman 2012; Schlemmer 2008). Regarding the transmission mechanisms at play, the CRS as an individual-level measure of religiosity enables us to pinpoint the impact pathway of religion to labor market performances to the individual level. The effects identified are not confounded by social capital or institutional effects. Individual religiosity seems to foster work ethic and to provide coping mechanisms that find their expression in improved economic status (Freeman 2012; Masondo 2013). The tentative result of a positive relationship of African traditional religion and labor market outcomes resonates with Öhlmann and Hüttel (2018), who show a positive effect of African traditional religion on household income. However, further investigations specifically focusing on African traditional religion and using more refined instruments are necessary to shed a more differentiated light on the role of African traditional religion with respect to economic performance.

Methodologically, this study contributes to the literature on religion and economic performance in two ways. First, it proposes a novel way to control for the endogeneity of religion by using experiences of contingency as instrumental variables to create exogenous variation in religiosity. The data show that contingency experiences are relevant instruments of religiosity. These experiences of "existential insecurity" (Norris and Inglehart 2011), such as the death of a family member, are positively correlated with levels of religiosity. To substantiate the validity of the instruments (which cannot be tested), I examine various hypothetical alternative pathways from contingency to labor market performance. There is no indication that there are other transmission mechanisms than through religiosity. I therefore conclude that the use of contingency experience as an instrumental variable is a viable approach to deal with the endogeneity of religion with respect to economic performance in microeconomics studies-particularly in those cases where randomized controlled trials à la Bryan et al. (2021) are not feasible. At the same time, this approach also has its limitations. One caveat is that there might be other, unknown pathways from contingency experience through religiosity. While I assessed this in a series of alternative hypotheses, the possibility that this might be the case can never be fully excluded. While the approach presented in this paper is never as clear-cut as randomized controlled trials, it can be more easily applied in cross-sectional studies. Another caveat is that the data used in this study do not offer more refined measures of contingency experience. Only one indicator used here, the experience of death in close social proximity, is robust against the argument that reverse causation might be an issue. A more refined interview inventory on contingency experience might further substantiate the validity. One specific desideratum is the inclusion of a time dimension regarding contingency experiences, as their effect on religiosity has been shown to diminish with time (see, for example, Bentzen 2019). Future research should hence build on this approach by developing better indicators of contingency experience and by applying it in studies using panel data. The second methodological contribution is the use of the Centrality of Religiosity Scale to distinguish between individual religious intensity and religious affiliation. The analysis demonstrates that applying the CRS to empirically distinguish between religiosity and religious tenets provides novel insights into the economic effects of religion and the transmission mechanisms from religion to 
economic performance. Future research using sophisticated measures of religiosity such as the CRS could substantially advance the research on religion and economic performance.

Furthermore, subsequent research should pay attention to the following aspects that constitute limitations of the present study. First, this investigation conceptually distinguishes between religiosity and religious content by using affiliation as a proxy of theological tenets. While I argue that this is feasible considering the frequency of religious switching in the South African context and because of the high context-relevance of the religion categories employed here, affiliation might still be a relatively weak indicator of religious content. Further studies should hence include more refined operationalizations of religious content in addition to affiliation. This might further elucidate the interplay of religiosity and religious content. Second, future research should operationalize the social level of religion in measurements of religious social capital, which has been argued to be an additional pathway through which religion affects economic outcomes (see, for example, Bompani 2010; Schlemmer 2008; Selinger 2004; Swart 2006, 2017; Wepener et al. 2010). Pursuing this line of research in quantitative studies might further refine our understanding of the relationship between religion and economic variables at the micro level. A third limitation of the present study is the relatively small sample size and the resultant statistical power. As Beck (2016) as well as Beck and Gundersen (2016) successfully demonstrate, the relationship of religion and economic performance might be heterogeneous not only across different religious communities but also differ according to wage quantiles and gender. There might also be interaction effects of religiosity and affiliation-for example, in the sense that religious content might affect economic performance in the group of those with higher religiosity. Larger studies allowing the analysis of potential non-linearities regarding religiosity and interaction effects between affiliation, religious beliefs, religiosity, and gender would be desirable.

\section{Conclusions}

Against the background of an increasing number of studies on the relationship of religion and economic performance, this is one of the few studies investigating the effect of religion on economic performance in a developing country context. Analyzing recent survey data in a novel identification strategy, this study provides evidence that religion does play a role in improving labor market performance in the high unemployment context of South Africa. Referring to the question raised in the title, "is it what you believe or how much?", the article shows that the intensity of religiosity has the decisive role. What seems to make the difference is not the specific set of theological tenets of a religious community but rather the extent to which religion is relevant in daily life. Relating this back to the Weberian hypothesis of the Protestant ethic, we can partially confirm and partially reject Weber's postulations: While we find high religiosity to positively affect economic performance, specific Christian doctrines do not seem to play the decisive role. This resonates with Eisenstadt's (1968) trans-religious notion of the "transformative capacity" of religion.

Moreover, the findings substantiate the emerging conclusion from the religion and development discourse in academia and development practice that religious communities are vital resources for development. A desideratum for further work would be to investigate how the economically conducive transformative potential of religiosity could be made fruitful for labor market policies and economic development programs.

Funding: The data collection for this research was financed by RWI-Leibniz Institute for Economic Research and Humboldt-Universität zu Berlin. Moreover, I acknowledge support by the German Research Foundation (DFG) and the Open Access Publication Fund of Humboldt-Universität zu Berlin.

Institutional Review Board Statement: The Livelihoods, Religion and Youth Survey received ethical clearance through the Turfloop Research Ethics Committee at University of Limpopo, South Africa, under the project number TREC/61/2016: IR. The Turfloop Research Ethics Committee is registered with the South African National Health Research Ethics Council, Registration Number: REC-0310111-031. 
Informed Consent Statement: All respondents gave their informed consent for inclusion before they participated in the survey.

Data Availability Statement: Data is available on request.

Acknowledgments: The author sincerely thanks Jochen Kluve for excellent advice in the research process and in drafting this article. Moreover, many thanks are due to two anonymous reviewers as well as the participants of the Association for the Study of Religion, Economics, and Culture Europe Conference 2019, the Development Economics Network Berlin Discussion Round, the Doctoral Workshop of the Development Economics Committee of the German Economic Association 2018, the University of Pretoria Economics Department Seminar, the Berlin Network of Labor Market Research 2017 Winter Workshop, and the Development Economics Network Berlin 2017 Workshop for highly constructive comments. Any remaining errors are mine. The Livelihoods, Religion and Youth Survey, forming the empirical basis of this paper, was conducted in close collaboration with the University of Limpopo, South Africa, where special thanks are due to J.J. Hlongwane, Marelize Kellermann, and David Norris, as well as the colleagues at the Department of Agricultural Economics and Animal Production for providing support and advice. The data collection was made possible by logistical support from Statistics South Africa (especially Johnny Monyebodu), the hard work of 18 field workers, and the openness of the members of 1039 households to share their personal information with the researchers. This is gratefully acknowledged.

Conflicts of Interest: The author declares no conflict of interest. The funders had no role in the design of the study; in the collection, analyses, or interpretation of data; in the writing of the manuscript, or in the decision to publish the results.

\section{Appendix A}

\section{Robustness Checks}

I perform the following robustness checks on the results. First, I estimate linear versions of Equation (1) using ordinary least squares (OLS) and instrumental variables versions of Equations (4), (5), and (8)-(11) using two-stage least squares (2SLS) estimation. This approach assumes labor market outcomes to be continuous. Even though this is not the case, the models provide additional indications on the robustness of the results of the ordered probit instrumental variable model and provide a set of identification tests not available for the non-linear case. The results of the models in Tables 6 and 7 but using OLS and 2SLS are reported in Tables A1 and A2. They are very similar to the ordered probit and instrumental variable ordered probit results. Tests for weak instruments (Kleibergen and Paap 2006; Sanderson and Windmeijer 2016) and weak instrument robust inference (Anderson and Rubin 1949) show that the results are largely robust to weak identification. The results in Table A1 corroborate the results in Table 6. Most coefficients are of similar magnitudes and have similar significance levels. This holds true for the instrumental variable estimations in Table A2 (corresponding to the IV ordered probit Table 7). Two differences are that in Models (2) and (4) of Table A2, which use Experience of death as instrument for Religiosity, the coefficient of Religiosity is only weakly significant (Model (2)) and not significant (Model (4)). This is likely due to the less adequate fit of the linear model, as it assumes the ordinal outcome to be linear. In the footer of Table A2, I provide the Anderson and Rubin (1949) $\chi^{2}$-statistics for weak-instrument robust inference and indicate the significance levels of the Anderson-Rubin test. We can reject the null hypothesis that the endogenous regressors are jointly equal to zero in all five models (though in Model 5 only with $p=0.1$ ). Moreover, I provide the Sanderson and Windmeijer (2016) conditional $F$-statistics to test whether each endogenous regressor is identified and the Kleibergen and Paap (2006) Wald F-statistics to test for weak identification of all the endogenous regressors jointly. In the case of one endogenous regressor, both statistics are the same. In Models (1) and (2), we can reject the null hypothesis of weak instruments: in Model (1), the Kleibergen-Paap F-value of 25.97 exceeds the Stock and Yogo (2005) critical value of 16.38 when allowing for a maximal size distortion of $10 \%$; in Model (2), the value exceeds the Stock-Yogo critical value of 6.66 when allowing for a maximal size distortion of $20 \%$. The Kleibergen-Paap F-statistics are substantially lower for the models with three 
endogenous variables; there seems to be particular reason for concern regarding Model (4). However, no formal testing is possible, as no critical values for the case of three endogenous regressors have been tabulated. Using the Sanderson-Windmeijer F-statistics in Models (3) and (5), we can reject the hypothesis of weak identification for each endogenous regressor when allowing for a maximal relative bias of 5\% (Stock-Yogo critical value: 13.91) and, in one case, $10 \%$ (Stock-Yogo critical value: 9.08). For Model (4), we cannot reject the null hypothesis that each endogenous regressor is equal to zero even when allowing for a maximal relative bias of $30 \%$. All three Sanderson-Windmeijer F-values in this model are below the critical value of 5.39. I conclude that the results are largely robust to weak identification.

Second, I estimate Equation (1) using a multinomial probit version of Model (4) in Table 6, which allows the estimation coefficients to differ for each outcome and does not assume the outcomes to be in any order of preference. The results are also confirmed in the multinomial setting. I treat $0=$ "not working and not actively looking for work" as the base category. Similar to Model (4) in Table 6, CRS and African traditional religion have positive and significant coefficients for outcomes 1, 2, and 3 (see Table A3 in Appendix A). In this setting, a standard deviation of CRS increases the probability of actively looking for work by 17.1 percentage points, the probability of being in informal employment by 23.6 percentage points, and the probability of formal employment by 21.0 percentage points with respect to the base category.

Third, to further hedge against the possibility that the ordinary scale of labor market outcomes might inadequately reflect the labor market situation, I estimate binary outcome models for the different labor market outcomes. In those models, Labor is a binary indicator of being at least on a specific level of labor market outcomes outlined in Table 5 (i.e., employment in the formal sector, employment in informal sector, or actively looking for work). Table A4 presents the results of the linear probability models. In Models (1) to (5), the dependent variable is "being (self-)employed in the formal sector". Models (6) to (10) estimate the probability of being in informal or formal (self-)employment. The dependent variable in Models (11) to (15) is the broadest indicator of labor market performance: the outcome is 1 if a person is (self-)employed in the formal or informal labor market or actively looking for work. The results are again similar to the ordered probit and instrumental variable ordered probit results. In the OLS estimations, Models (1) and (2), CRS does not have a significant coefficient, but in Models (6) and (7) and Models (11) and (12), the coefficient is positive and of similar magnitude as the marginal effect estimates from the ordered probit estimations displayed in Table 6. CRS has a significant coefficient in nearly all 2SLS estimations. An increase in CRS by one standard deviation increases the probability of being in formal (self-)employment by 22.7 and 29.2 percentage points (Models (3) and (5)). The fact that CRS does not have a significant coefficient in Model (4) is likely due to weak instrument issues, as reflected in the low Anderson-Rubin $\chi^{2}$-statistic of 0.04 . Models (8) to (10) show a standard deviation increase in CRS to increase the probability of being in formal or informal employment by between 32.6 and 42.1 percentage points. With respect to the models in which the outcome is formal sector employment, informal sector employment, or actively looking for work, it increases the probability of a positive outcome by between 26.0 and 42.4 percentage points (Models (13) to (15)). As there might be a loss in precision due to weak instrument issues in Models (9) and (14), the comparatively large coefficients of these models can be treated as the upper bound of the effect of CRS. With respect to the coefficient magnitudes, we observe a similar pattern as in the ordered probit models, with coefficients of $C R S$ being between six- and ten-fold the size of the OLS coefficients. The results also confirm the ordered probit results regarding Church and African traditional. Church membership does not have a significant coefficient in any of the models. The indicator of African traditional religion is significant only in the OLS estimations of the probability of working or actively looking for work. In Models (11) and (12), African traditional religious practice goes along with a higher probability by 4.6 to 5.2 
percentage points for working or actively looking for work. However, it is not significant in any of the 2SLS estimations.

Fourth, I conduct an additional analysis for the subsample of those persons not in formal employment to specifically analyze whether CRS drives the probability of actively looking for employment (Table A5). While the reasons for not finding employment might be structural and out of the influence of a given individual (e.g., determined by parents' earlychildhood educational choices), the variable of actively looking for work directly relates to the individual propensity of engaging in employment. Both the OLS and 2SLS coefficients are in a similar region of magnitude as their respective counterparts in Table A4 (columns (10) to (15)). CRS seems to increase the probability of actively looking for employment among those not working. However, the instrumental variable estimations do not yield significant coefficients of $C R S$, as the smaller sample size leads to larger standard errors. The low Anderson-Rubin $\chi^{2}$-values of the 2SLS models furthermore suggest weak identification to be a problem when using this smaller subsample.

Fifth, I conduct subsample analyses for those people not affiliated with any church and for those who do not practice African traditional religion. I thereby verify whether $C R S$ has a positive effect on labor market performance regardless of church affiliation and practice of African traditional religion. The results (Table A6) show that this is the case. $C R S$ positively affects labor market performance even in the non-affiliated subgroups. An OLS/2SLS version (Table A7) confirms these results.

Table A1. Results ordinary least squares estimation.

\begin{tabular}{|c|c|c|c|c|c|}
\hline & (1) & (2) & (3) & (4) & (5) \\
\hline & OLS & OLS & OLS & OLS & OLS \\
\hline \multirow{2}{*}{$\begin{array}{l}\text { Religiosity } \\
\text { (std.ized) }\end{array}$} & & & $0.095^{* *}$ & $0.095^{* *}$ & $0.095^{* * *}$ \\
\hline & & & $(0.038)$ & $(0.038)$ & $(0.033)$ \\
\hline African traditional & 0.097 & $0.124^{* *}$ & $0.102 *$ & $0.125^{* *}$ & \\
\hline Church & $\begin{array}{l}0.127 * \\
(0.074)\end{array}$ & & $\begin{array}{c}0.017 \\
(0.083)\end{array}$ & & \\
\hline Apostolic church & & $\begin{array}{l}-0.053 \\
(0.098)\end{array}$ & & $\begin{array}{l}-0.159 \\
(0.104)\end{array}$ & \\
\hline Mission church & & $\begin{array}{c}0.166 \\
(0.111)\end{array}$ & & $\begin{array}{c}0.078 \\
(0.114)\end{array}$ & \\
\hline $\begin{array}{l}\text { Pentecostal- } \\
\text { Charismatic } \\
\text { church }\end{array}$ & & $\begin{array}{l}0.234 \text { * } \\
(0.127)\end{array}$ & & $\begin{array}{c}0.099 \\
(0.135)\end{array}$ & \\
\hline $\begin{array}{l}\text { Zion Christian } \\
\text { church }\end{array}$ & & $\begin{array}{l}0.199 * * \\
(0.088)\end{array}$ & & $\begin{array}{c}0.088 \\
(0.096)\end{array}$ & \\
\hline Other church & & $\begin{array}{c}0.058 \\
(0.128)\end{array}$ & & $\begin{array}{l}-0.064 \\
(0.139)\end{array}$ & \\
\hline Ward indicators & Yes & Yes & Yes & Yes & Yes \\
\hline Covariates & Yes & Yes & Yes & Yes & Yes \\
\hline Adj. $R^{2}$ & 0.20 & 0.20 & 0.20 & 0.21 & 0.20 \\
\hline$F$ & 11.78 & 11.20 & 11.48 & 10.97 & 11.84 \\
\hline
\end{tabular}

Note-Dependent variable: employment status $(0=$ not looking for work, $1=$ actively looking for work, $2=$ employed in informal sector, 3 = employed in formal sector); covariates include sociodemographic characteristics at individual and household level, education, social capital, migration, language, and social security grant receipt (see Table 1, Panel I); constant omitted; standard errors in parentheses clustered at household level; $N=1086 ;^{*} p<0.1,{ }^{* *} p<0.05,{ }^{* * *} p<0.01$. 
Table A2. Results two-stage least squares estimation.

\begin{tabular}{|c|c|c|c|c|c|}
\hline & (1) & (2) & (3) & (4) & (5) \\
\hline & 2SLS & 2SLS & 2SLS & 2SLS & 2SLS \\
\hline Religiosity (std.ized) & $\begin{array}{l}0.813^{* * *} \\
(0.233)\end{array}$ & $\begin{array}{l}0.875^{*} \\
(0.491)\end{array}$ & $\begin{array}{l}0.943 * * * \\
(0.272)\end{array}$ & $\begin{array}{c}1.267 \\
(0.842)\end{array}$ & $\begin{array}{c}0.447 * * \\
(0.196)\end{array}$ \\
\hline African traditional & & & $\begin{array}{c}0.284 \\
(0.488)\end{array}$ & $\begin{array}{c}0.563 \\
(0.850)\end{array}$ & $\begin{array}{l}-0.140 \\
(0.376)\end{array}$ \\
\hline Church & & & $\begin{array}{l}-0.942 \\
(0.860)\end{array}$ & $\begin{array}{l}-1.317 \\
(1.512)\end{array}$ & $\begin{array}{l}-0.369 \\
(0.547)\end{array}$ \\
\hline $\begin{array}{c}\text { Ward indicators } \\
\text { Covariates }\end{array}$ & $\begin{array}{l}\text { Yes } \\
\text { Yes }\end{array}$ & $\begin{array}{l}\text { Yes } \\
\text { Yes }\end{array}$ & $\begin{array}{l}\text { No } \\
\text { Yes }\end{array}$ & $\begin{array}{l}\text { No } \\
\text { Yes }\end{array}$ & $\begin{array}{l}\text { No } \\
\text { Yes }\end{array}$ \\
\hline $\begin{array}{c}\text { First stages: } \\
\text { Religiosity } \\
\text { Contingency experience }\end{array}$ & $\begin{array}{l}0.704^{* * *} \\
(0.138)\end{array}$ & & $\begin{array}{l}0.751 * * * \\
(0.141)\end{array}$ & & \\
\hline Experience of death & & $\begin{array}{c}0.235^{* * *} \\
(0.089)\end{array}$ & & $\begin{array}{c}0.250 * * * \\
(0.091)\end{array}$ & \\
\hline Mean religiosity (std.ized) & & & & & $\begin{array}{l}0.176^{* * *} \\
(0.040)\end{array}$ \\
\hline $\begin{array}{c}\text { Church } \\
\text { Share church (std.ized) }\end{array}$ & & & $\begin{array}{c}0.059 * * * \\
(0.015)\end{array}$ & $\begin{array}{c}0.062^{* * *} \\
(0.015)\end{array}$ & $\begin{array}{c}0.069 * * * \\
(0.017)\end{array}$ \\
\hline $\begin{array}{c}\text { African traditional } \\
\text { Share Afr. traditional (std.ized) }\end{array}$ & & & $\begin{array}{c}0.097^{* * *} \\
(0.017)\end{array}$ & $\begin{array}{c}0.097^{* * *} \\
(0.017)\end{array}$ & $\begin{array}{l}0.106^{* * *} \\
(0.018)\end{array}$ \\
\hline $\begin{array}{c}\text { First stage statistics: } \\
\text { Sanderson-Windmeijer F (Religiosity) } \\
\text { Sanderson-Windmeijer } F \text { (Church) } \\
\text { Sanderson-Windmeijer F (Afr. trad.) } \\
\text { Kleibergen-Paap Wald } F \\
\text { Anderson-Rubin Wald } \chi^{2}\end{array}$ & $\begin{array}{c}25.97 \\
18.82 * * *\end{array}$ & $\begin{array}{c}6.89 \\
5.02 * *\end{array}$ & $\begin{array}{c}20.27 \\
12.26 \\
18.74 \\
3.8 \\
24.04^{* * *}\end{array}$ & $\begin{array}{c}2.90 \\
3.19 \\
3.98 \\
0.95 \\
8.08 * *\end{array}$ & $\begin{array}{c}30.17 \\
18.31 \\
32.09 \\
4.41 \\
7.21 *\end{array}$ \\
\hline
\end{tabular}

Note-Dependent variable: employment status $(0=$ not looking for work, $1=$ actively looking for work, $2=$ employed in informal sector, $3=$ employed in formal sector); covariates include sociodemographic characteristics at individual and household level, education, social capital, migration, language, and social security grant receipt (see Table 1, Panel I); constant omitted; standard errors in parentheses clustered at household level; each first stage includes the full set of covariates; $N=1086$; ${ }^{*} p<0.1,{ }^{* *} p<0.05,{ }^{* * *} p<0.01$.

Table A3. Estimation results multinomial probit model.

\begin{tabular}{|c|c|c|c|}
\hline Outcome Labor $=$ & $\begin{array}{c}1 \\
\text { Coefficient } \\
\text { (SE) }\end{array}$ & $\begin{array}{c}2 \\
\text { Coefficient } \\
\text { (SE) }\end{array}$ & $\begin{array}{c}3 \\
\text { Coefficient } \\
\text { (SE) }\end{array}$ \\
\hline Religiosity (std.ized) & $\begin{array}{c}0.171 * * \\
(0.085)\end{array}$ & $\begin{array}{c}0.236 * * \\
(0.097)\end{array}$ & $\begin{array}{c}0.210 * * \\
(0.092)\end{array}$ \\
\hline African traditional & $\begin{array}{l}0.265 * \\
(0.145)\end{array}$ & $\begin{array}{c}0.368 * * \\
(0.162)\end{array}$ & $\begin{array}{c}0.3611^{* *} \\
(0.154)\end{array}$ \\
\hline Apostolic church & $\begin{array}{l}-0.189 \\
(0.255)\end{array}$ & $\begin{array}{l}-0.104 \\
(0.271)\end{array}$ & $\begin{array}{l}-0.418 \\
(0.275)\end{array}$ \\
\hline Mission church & $\begin{array}{c}0.011 \\
(0.251)\end{array}$ & $\begin{array}{c}0.015 \\
(0.279)\end{array}$ & $\begin{array}{c}0.187 \\
(0.270)\end{array}$ \\
\hline Pentecostal-Charismatic church & $\begin{array}{l}-0.058 \\
(0.300)\end{array}$ & $\begin{array}{c}0.141 \\
(0.337) \\
\end{array}$ & $\begin{array}{c}0.337 \\
(0.324) \\
\end{array}$ \\
\hline Zion Christian church & $\begin{array}{c}0.194 \\
(0.226)\end{array}$ & $\begin{array}{c}0.300 \\
(0.250)\end{array}$ & $\begin{array}{c}0.318 \\
(0.239)\end{array}$ \\
\hline Other/unknown church & $\begin{array}{l}-0.453 \\
(0.317)\end{array}$ & $\begin{array}{c}0.060 \\
(0.323)\end{array}$ & $\begin{array}{c}-0.425 \\
(0.342)\end{array}$ \\
\hline $\begin{array}{c}\text { Ward indicators } \\
\text { Covariates }\end{array}$ & $\begin{array}{l}\text { Yes } \\
\text { Yes }\end{array}$ & $\begin{array}{l}\text { Yes } \\
\text { Yes }\end{array}$ & $\begin{array}{l}\text { Yes } \\
\text { Yes }\end{array}$ \\
\hline
\end{tabular}

Note-Dependent variable: employment status $(0=$ not looking for work (base category), $1=$ actively looking for work, $2=$ employed in informal sector, 3 = employed in formal sector); covariates include sociodemographic characteristics at individual and household level, education, social capital, migration, language, and social security grant receipt (see Table 1, Panel I); constant omitted; standard errors in parentheses clustered at household level; $N=1086 ; \chi^{2}=489.08 ; * p<0.1,{ }^{* *} p<0.05$. 
Table A4. Estimation results linear probability model.

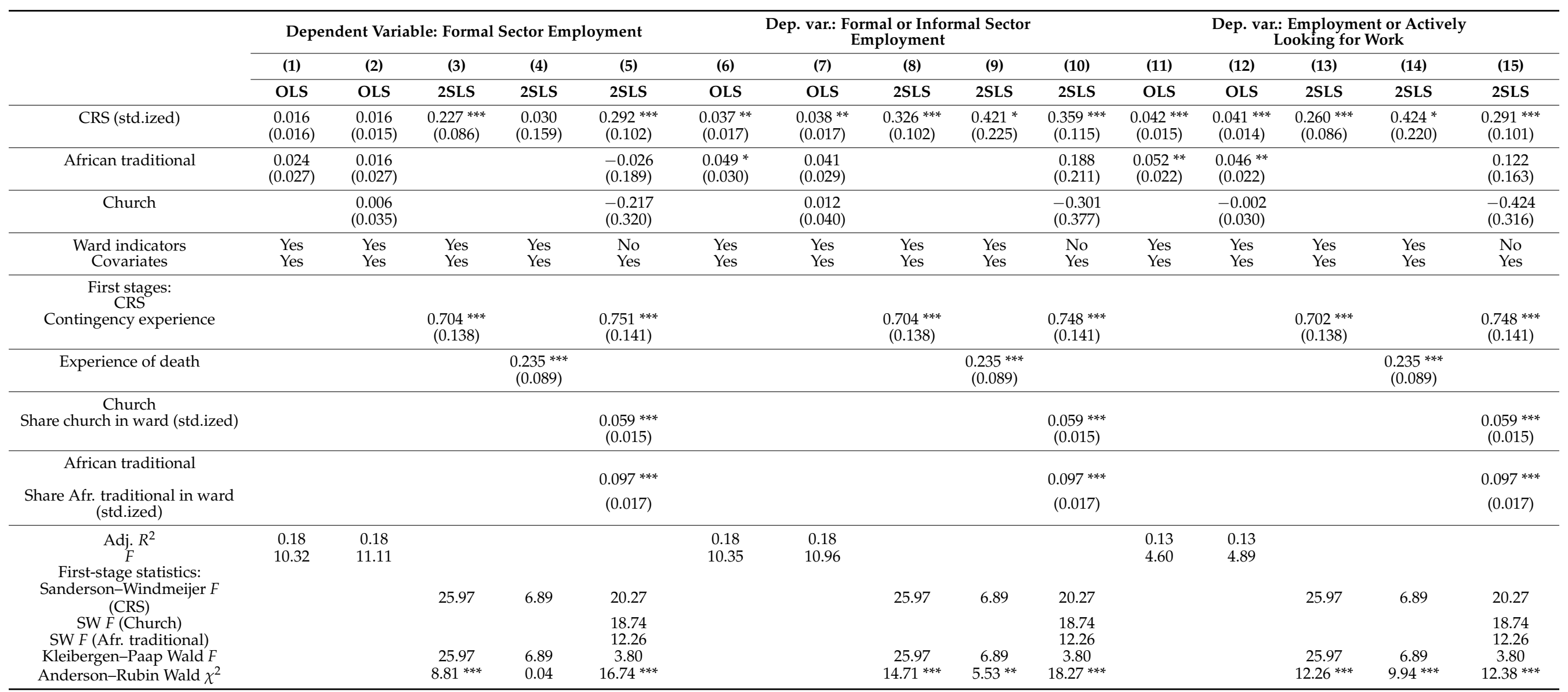

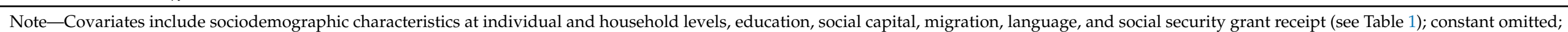
standard errors in parentheses clustered at household level; each first stage includes the full set of covariates; $N=1086 ;{ }^{*} p<0.1,{ }^{* *} p<0.05, * * * p<0.01$. 
Table A5. Estimation results linear probability model—subsample of persons not (self-)employed in the formal sector.

\begin{tabular}{|c|c|c|c|c|c|}
\hline & (1) & (2) & (3) & (5) & (7) \\
\hline & OLS & OLS & 2SLS & 2SLS & 2SLS \\
\hline Religiosity (std.ized) & $0.049^{* *}$ & $0.047^{* *}$ & 0.161 & 0.519 & 0.204 \\
\hline & $(0.022)$ & $(0.022)$ & $(0.111)$ & $(0.492)$ & $(0.130)$ \\
\hline African traditional & $0.079 * *$ & $0.066^{*}$ & & & 0.077 \\
\hline & $(0.039)$ & $(0.037)$ & & & (0.171) \\
\hline Church & & $\begin{array}{l}-0.021 \\
(0.049)\end{array}$ & & & $\begin{array}{l}-0.352 \\
(0.336)\end{array}$ \\
\hline Ward indicators & Yes & Yes & Yes & Yes & No \\
\hline Covariates & Yes & Yes & Yes & Yes & Yes \\
\hline $\begin{array}{c}\text { First stages: } \\
\text { Religiosity }\end{array}$ & & & & & \\
\hline Contingency experience & & & $\begin{array}{c}0.720 * * * \\
(0.179)\end{array}$ & & $\begin{array}{c}0.774^{* * *} \\
(0.184)\end{array}$ \\
\hline Experience of death & & & & $\begin{array}{c}0.163 \\
(0.117) \\
\end{array}$ & \\
\hline $\begin{array}{c}\text { Church } \\
\text { Share church per ward (std.ized) }\end{array}$ & & & & & $\begin{array}{c}0.073^{* * *} \\
(0.020)\end{array}$ \\
\hline $\begin{array}{c}\text { African traditional } \\
\text { Share Afr. traditional per ward } \\
\text { (std.ized) }\end{array}$ & & & & & $\begin{array}{c}0.139 * * * \\
(0.025)\end{array}$ \\
\hline Adj. $R^{2}$ & 0.18 & 0.18 & & & \\
\hline$F$ & 6.40 & 6.88 & & & \\
\hline $\begin{array}{l}\text { First stage statistics: } \\
\text { Sanderson-Windmeijer F (Religiosity) }\end{array}$ & & & 16.24 & 1.96 & 16.06 \\
\hline Sanderson-Windmeijer $F$ (Church) & & & & & 32.97 \\
\hline Sanderson-Windmeijer $F$ (Afr. trad.) & & & & & 12.07 \\
\hline Kleibergen-Paap Wald $F$ & & & 16.24 & 1.96 & 4.23 \\
\hline Anderson-Rubin Wald $\chi^{2}$ & & & 2.32 & $2.74 *$ & 2.93 \\
\hline
\end{tabular}

Note-Dependent variable: indicator of employment status (= 1 actively looking for work); sub-sample of persons not in formal employment; covariates include sociodemographic characteristics at individual and household level, education, social capital, migration, language, and social security grant receipt (see Table 1, Panel I); constant omitted; standard errors in parentheses clustered at household level; each first stage includes the full set of covariates; $N=561 ;{ }^{*} p<0.1,{ }^{* *} p<0.05,{ }^{* * *} p<0.01$.

Table A6. Estimation results ordered probit model for subgroups of non-church members and non-ATR practitioners.

\begin{tabular}{|c|c|c|c|c|c|}
\hline & (1) & (2) & (3) & (4) & (5) \\
\hline & $\begin{array}{c}\text { Ordered } \\
\text { Probit, } \\
\text { Subsample Non-Church }\end{array}$ & $\begin{array}{c}\text { Ordered } \\
\text { Probit, } \\
\text { Subsample Non-ATR }\end{array}$ & $\begin{array}{l}\text { IV Ordered Probit, } \\
\text { Subsample } \\
\text { Non-Church }\end{array}$ & $\begin{array}{l}\text { IV Ordered Probit, } \\
\text { Subsample } \\
\text { Non-Church }\end{array}$ & $\begin{array}{l}\text { IV Ordered Probit, } \\
\text { Subsample } \\
\text { Non-ATR }\end{array}$ \\
\hline Religiosity (std.ized) & $\begin{array}{l}0.214^{* * *} \\
(0.077)\end{array}$ & $\begin{array}{l}0.119 * \\
(0.064)\end{array}$ & $\begin{array}{l}0.824 * * * \\
(0.180)\end{array}$ & $\begin{array}{l}0.705^{* * *} \\
(0.209)\end{array}$ & $\begin{array}{l}0.859 * * * \\
(0.227)\end{array}$ \\
\hline African traditional & $\begin{array}{l}-0.012 \\
(0.147)\end{array}$ & & & $\begin{array}{l}-1.138 * * \\
(0.540)\end{array}$ & \\
\hline Church & & $\begin{array}{l}-0.154 \\
(0.143)\end{array}$ & & & $\begin{array}{l}-1.841 \\
(1.219)\end{array}$ \\
\hline $\begin{array}{l}\text { Ward indicators } \\
\text { Covariates }\end{array}$ & $\begin{array}{l}\text { Yes } \\
\text { Yes }\end{array}$ & $\begin{array}{l}\text { Yes } \\
\text { Yes }\end{array}$ & $\begin{array}{l}\text { Yes } \\
\text { Yes }\end{array}$ & $\begin{array}{l}\text { No } \\
\text { Yes }\end{array}$ & $\begin{array}{l}\text { No } \\
\text { Yes }\end{array}$ \\
\hline $\begin{array}{l}\text { First stages: } \\
\text { Religiosity (std.ized) } \\
\text { Contingency } \\
\text { experience }\end{array}$ & & & $\begin{array}{c}0.820^{* * *} \\
(0.265)\end{array}$ & $\begin{array}{c}0.859^{* * *} \\
(0.277)\end{array}$ & $\begin{array}{c}0.711^{* * *} \\
(0.165)\end{array}$ \\
\hline $\begin{array}{l}\text { African traditional } \\
\text { Share Afr. trad. } \\
\text { (std.ized) }\end{array}$ & & & & $\begin{array}{c}0.097^{* * *} \\
(0.034)\end{array}$ & \\
\hline $\begin{array}{l}\text { Church } \\
\text { Share church (std.ized) }\end{array}$ & & & & & $\begin{array}{l}0.032 * \\
(0.016)\end{array}$ \\
\hline $\begin{array}{c}\text { Observations } \\
\chi^{2}\end{array}$ & $\begin{array}{c}292 \\
114.65\end{array}$ & $\begin{array}{c}563 \\
203.18\end{array}$ & 292 & 292 & 563 \\
\hline
\end{tabular}

Note-Dependent variable: employment status $(0=$ not looking for work, $1=$ actively looking for work, $2=$ employed in informal sector, 3 = employed in formal sector); covariates include sociodemographic characteristics at individual and household level, education, social capital, migration, language, and social security grant receipt (see Table 1, Panel I); cut-offs omitted; standard errors in parentheses clustered at household level; each first stage includes the full set of covariates; ${ }^{*} p<0.1,{ }^{* *} p<0.05,{ }^{* * *} p<0.01$. 
Table A7. Estimation results least squares estimation for subsamples of non-church members and non-ATR practitioners.

\begin{tabular}{|c|c|c|c|c|c|}
\hline & (1) & (2) & (3) & (5) & (8) \\
\hline & $\begin{array}{c}\text { OLS } \\
\text { Non-Church }\end{array}$ & $\begin{array}{c}\text { OLS } \\
\text { Non-ATR }\end{array}$ & $\begin{array}{c}\text { 2SLS } \\
\text { Non-Church }\end{array}$ & $\begin{array}{c}\text { 2SLS } \\
\text { Non-Church }\end{array}$ & $\begin{array}{c}\text { 2SLS } \\
\text { Non-ATR }\end{array}$ \\
\hline Religiosity (std.ized) & $\begin{array}{l}0.170 * * * \\
(0.064)\end{array}$ & $\begin{array}{l}0.102 * \\
(0.054)\end{array}$ & $\begin{array}{l}0.930 * * * \\
(0.357)\end{array}$ & $\begin{array}{l}0.974^{* *} \\
(0.395)\end{array}$ & $\begin{array}{l}1.428 * * \\
(0.594)\end{array}$ \\
\hline African traditional & $\begin{array}{c}0.001 \\
(0.126) \\
\end{array}$ & & & $\begin{array}{l}-1.455 \\
(1.027)\end{array}$ & \\
\hline Church & & $\begin{array}{l}-0.110 \\
(0.122)\end{array}$ & & & $\begin{array}{l}-4.003 * \\
(2.275)\end{array}$ \\
\hline $\begin{array}{l}\text { Ward indicators } \\
\text { Covariates }\end{array}$ & $\begin{array}{l}\text { Yes } \\
\text { Yes }\end{array}$ & $\begin{array}{l}\text { Yes } \\
\text { Yes }\end{array}$ & $\begin{array}{l}\text { Yes } \\
\text { Yes }\end{array}$ & $\begin{array}{l}\text { No } \\
\text { Yes }\end{array}$ & $\begin{array}{l}\text { No } \\
\text { Yes }\end{array}$ \\
\hline $\begin{array}{c}\text { First stages: } \\
\text { Religiosity } \\
\text { Contingency experience }\end{array}$ & & & $\begin{array}{l}0.820 * * * \\
(0.282)\end{array}$ & $\begin{array}{l}0.869 * * * \\
(0.273)\end{array}$ & $\begin{array}{l}0.846^{* * *} \\
(0.186)\end{array}$ \\
\hline $\begin{array}{c}\text { Church } \\
\text { Share church (std.ized) }\end{array}$ & & & & & $\begin{array}{l}0.050 * * * \\
(0.019)\end{array}$ \\
\hline $\begin{array}{c}\text { African traditional } \\
\text { Share Afr. trad. (std.ized) }\end{array}$ & & & & $\begin{array}{c}0.097 * * * \\
(0.033)\end{array}$ & \\
\hline $\begin{array}{c}\text { Observations } \\
\text { Adj. } R^{2} \\
F\end{array}$ & $\begin{array}{l}292 \\
0.20 \\
5.30\end{array}$ & $\begin{array}{l}563 \\
0.24 \\
9.47\end{array}$ & 292 & 292 & 563 \\
\hline $\begin{array}{c}\text { First stage statistics: } \\
\text { Sanderson-Windmeijer } F \\
\text { (Religiosity) }\end{array}$ & & & 8.42 & 9.76 & 6.19 \\
\hline $\begin{array}{l}\text { Sanderson-Windmeijer } F \\
\text { (Church) }\end{array}$ & & & & & 4.69 \\
\hline $\begin{array}{c}\text { Sanderson-Windmeijer } F \text { (Afr. } \\
\text { trad.) }\end{array}$ & & & & 8.18 & \\
\hline Kleibergen-Paap Wald $F$ & & & 8.42 & 4.06 & 2.34 \\
\hline Anderson-Rubin Wald $\chi^{2}$ & & & $11.59^{* * *}$ & $15.56^{* * *}$ & $19.75^{* * *}$ \\
\hline
\end{tabular}

Note-Dependent variable: employment status $(0=$ not looking for work, $1=$ actively looking for work, $2=$ employed in informal sector, 3 = employed in formal sector); covariates include sociodemographic characteristics at individual and household level, education, social capital, migration, language, and social security grant receipt (see Table 1, Panel I); constant omitted; standard errors in parentheses clustered at household level; each first stage includes the full set of covariates; ${ }^{*} p<0.1,{ }^{* *} p<0.05,{ }^{* * *} p<0.01$.

\section{References}

Adeyem, Oluwagbemiga, Kolawole Odusina, and Akinwole Akintoye. 2016. Religion and Labour Force Participation in Nigeria: Is There Any Inequality Among Women? African Journal of Reproductive Health 20: 75-84. [CrossRef] [PubMed]

African Development Bank. 2018. African Economic Outlook 2018. Abidjan: African Development Bank.

Aleksynska, Mariya, and Barry R. Chiswick. 2013. The Determinants of Religiosity Among Immigrants and the Native Born in Europe. Review of Economics of the Household 11: 563-98. [CrossRef]

Anderson, Allan. 2000. Zion and Pentecost. The Spirituality and Experience of Pentecostal and Zionist/Apostolic Churches in South Africa. Pretoria: University of South Africa.

Anderson, Allan. 2001. African Reformation: African Initiated Christianity in the 20th Century. Trenton: Africa World Press.

Anderson, Theodore W., and Herman Rubin. 1949. Estimation of the Parameters of a Single Equation in a Complete System of Stochastic Equations. Annals of Mathematical Statistics 20: 46-63. [CrossRef]

Ano, Gene G., and Erin B. Vasconcelles. 2005. Religious Coping and Psychological Adjustment to Stress. A Meta-Analysis. Journal of Clinical Psychology 61: 461-80. [CrossRef]

Arano, Kathleen G., and Benjamin F. Blair. 2008. Modeling Religious Behavior and Economic Outcome: Is the Relationship Bicausal? Evidence from a Survey of Mississippi Households. Journal of Socio-Economics 37: 2043-53. [CrossRef] 
Ardington, Cally, Anne Case, and Victoria Hosegood. 2009. Labor Supply Responses to Large Social Transfers. Longitudinal Evidence from South Africa. American Economic Journal: Applied Economics 1: 22-48. [CrossRef]

Asamoah-Gyadu, J. Kwabena. 2015. Pentecostalism and the Transformation of the African Christian Landscape. In Pentecostalism in Africa: Presence and Impact of Pneumatic Christianity in Postcolonial Societies. Edited by Martin Lindhardt. Leiden: Brill, pp. 100-14.

Ashforth, Adam. 2005. Witchcraft, Violence and Democracy in South Africa. Chicago: University of Chicago Press.

Audretsch, David B., Werner Bönte, and Jagannadha P. Tamvada. 2013. Religion, Social Class, and Entrepreneurial Choice. Journal of Business Venturing 28: 774-89. [CrossRef]

Banerjee, Abhijit, Sebastian Galiani, Jim Levinsohn, Zoë McLaren, and Ingrid Woolard. 2008. Why Has Unemployment Risen in the New South Africa? Economics of Transition 16: 715-40. [CrossRef]

Barro, Robert J., and Rachel M. McCleary. 2003. Religion and Economic Growth Across Countries. American Sociological Review 68: 760-81. [CrossRef]

Basten, Christoph, and Frank Betz. 2013. Beyond Work Ethic: Religion, Individual, and Political Preferences. American Economic Journal: Economic Policy 5: 67-91. [CrossRef]

Beck, Sedefka V. 2016. Wage Differentials in the United States: Does Religious Participation Matter? Journal for the Scientific Study of Religion 55: 558-78. [CrossRef]

Beck, Sedefka V., and Sara J. Gundersen. 2016. A Gospel of Prosperity? An Analysis of the Relationship Between Religion and Earned Income in Ghana, the Most Religious Country in the World. Journal for the Scientific Study of Religion 55: 105-29. [CrossRef]

Becker, Sascha O., and Ludger Woessmann. 2009. Was Weber Wrong? A Human Capital Theory of Protestant Economic History. The Quarterly Journal of Economics 124: 531-96. [CrossRef]

Becker, Sascha O., and Ludger Woessmann. 2013. Not the Opium of the People: Income and Secularization in a Panel of Prussian Counties. American Economic Review 103: 539-44. [CrossRef]

Becker, Sascha O., and Ludger Woessmann. 2018. Social Cohesion, Religious Beliefs, and the Effect of Protestantism on Suicide. Review of Economics and Statistics 100: 377-91. [CrossRef]

Bengtsson, Niklas. 2013. Catholics Versus Protestants: On the Benefit Incidence of Faith-Based Foreign Aid. Economic Development and Cultural Change 61: 479-502. [CrossRef]

Benjamin, Daniel, James Choi, and Geoffrey Fisher. 2016. Religious Identity and Economic Behavior. Review of Economics and Statistics 98: 617-37. [CrossRef]

Bentzen, Jeanet. 2019. Acts of God? Religiosity and Natural Disasters Across Subnational World Districts. The Economic Journal 129: 2295-321. [CrossRef]

Bentzen, Jeanet. 2020. In Crisis, We Pray: Religiosity and the Covid-19 Pandemic. Covid Economics 20: 52-108.

Berger, Peter L. 2010. Max Weber Is Alive and Well, and Living in Guatemala: The Protestant Ethic Today. The Review of Faith E International Affairs 8: 3-9. [CrossRef]

Bettendorf, Leon, and Elbert Dijkgraaf. 2010. Religion and Income: Heterogeneity Between Countries. Journal of Economic Behavior E Organization 74: 12-29.

Bettendorf, Leon, and Elbert Dijkgraaf. 2011. The Bicausal Relation Between Religion and Income. Applied Economics 43: 1351-63. [CrossRef]

Bompani, Barbara. 2010. Religion and Development from Below: Independent Christianity in South Africa. Journal of Religion in Africa 40: 307-30. [CrossRef]

Brañas-Garza, Pablo, Máximo Rossi, and Dayna Zaclicever. 2009. Individual's Religiosity Enhances Trust: Latin American Evidence for the Puzzle. Journal of Money, Credit and Banking 41: 555-66. [CrossRef]

Branson, Nicola, and Murray Leibbrandt. 2013. Educational Attainment and Labour Market Outcomes in South Africa, 1994-2010. OECD Economics Department Working Papers 1022. [CrossRef]

Bryan, Gharad, James Choi, and Dean Karlan. 2021. Randomizing Religion: The Impact of Protestant Evangelism on Economic Outcomes. The Quarterly Journal of Economics 136: 293-380. [CrossRef]

Buser, Thomas. 2015. The Effect of Income on Religiousness. American Economic Journal: Applied Economics 7: 178-95. [CrossRef]

Cantoni, Davide. 2015. The Economic Effects of the Protestant Reformation: Testing the Weber Hypothesis in the German Lands. Journal of the European Economic Association 13: 561-98. [CrossRef]

Chen, Daniel L., and Daniel M. Hungerman. 2014. Economics, Religion, and Culture. A Brief Introduction. Journal of Economic Behavior E Organization 104: 1-3. [CrossRef]

Chiswick, Barry R., and Jidong Huang. 2008. The Earnings of American Jewish Men: Human Capital, Denomination, and Religiosity. Journal for the Scientific Study of Religion 47: 694-709. [CrossRef]

Coleman, James S. 1988. Social Capital in the Creation of Human Capital. The American Journal of Sociology 94: S95-S120. [CrossRef]

Cornelissen, Thomas, and Uwe Jirjahn. 2012. Religion and Earnings: Is It Good to Be an Atheist with Religious Parental Background?". Economics Letters 117: 905-8. [CrossRef]

Cross, Catherine, Gerhardus C. Oosthuizen, and Craig Clark. 1993. Out of the Wind. The African Independent Churches and Youth Urbanization in Metropolitan Natal. A Report Prepared for the Co-Operative Programme on the Youth. Durban: Centre for Social and Development Studies, University of Natal.

Davies, Rob, and James Thurlow. 2010. Formal-Informal Economy Linkages and Unemployment in South Africa. South African Journal of Economics 78: 437-59. [CrossRef] 
De Jong, Eelke. 2011. Religious Values and Economic Growth: A Review and Assessment of Recent Studies. In Religion and Development: Ways of Transforming the World. Edited by Gerrie Ter Haar. New York: Oxford University Press, pp. 111-40.

Dehejia, Raheev, Thomas DeLeire, and Erzo F. Luttmer. 2007. Insuring Consumption and Happiness through Religious Organizations. Journal of Public Economics 91: 259-79. [CrossRef]

Dickow, Helga. 2012. Religion and Attitudes Towards Life in South Africa: Pentecostals, Charismatics and Reborns. Baden-Baden: Nomos.

Eisenstadt, Shmuel N. 1968. The Protestant Ethic Thesis in an Analytical and Comparative Framework. In The Protestant Ethic and Modernization: A Comparative View. Edited by Shmuel N. Eisenstadt. New York and London: Basic Books, pp. 3-45.

Freeman, Dena. 2012. The Pentecostal Ethic and the Spirit of Development. In Pentecostalism and Development: Churches, NGOs and Social Change in Africa. Edited by Dena Freeman. Basingstoke: Palgrave Macmillan, pp. 1-38.

Gifford, Paul. 2015. Christianity, Development and Modernity in Africa. London: Hurst.

Gruber, Jonathan H. 2005. Religious Market Structure, Religious Participation, and Outcomes: Is Religion Good for You? The B.E. Journal of Economic Analysis E Policy 5: 1-30. [CrossRef]

Guiso, Luigi, Paola Sapienza, and Luigi Zingales. 2003. People's Opium? Religion and Economic Attitudes. Journal of Monetary Economics 50: 225-82. [CrossRef]

Haynes, Jeffrey. 2009. Religion and Democratizations: An Introduction. Democratization 16: 1041-57. [CrossRef]

Heckman, James J. 1979. Sample Selection Bias as a Specification Error. Econometrica 47: 153. [CrossRef]

Heuser, Andreas. 2013. 'Refuse to Die in Poverty!' Armutsüberwindung und Varianten des Wohlstandsevangeliums in Afrika. Theologische Zeitschrift 69: 146-71.

Heuser, Andreas. 2015. Religio-Scapes of Prosperity Gospel: An Introduction. In Pastures of Plenty: Tracing Religio-Scapes of Prosperity Gospel in Africa and Beyond. Edited by Andreas Heuser. Frankfurt am Main: Peter Lang, pp. 15-29.

Heuser, Andreas. 2016. Charting African Prosperity Gospel Economies. HTS Teologiese Studies/Theological Studies 72: 1-9. [CrossRef]

Hock, Klaus. 2009. The Omnipresence of the Religious: Religion in Nigeria. In What the World Believes: Analysis and Commentary on the Religion Monitor 2008. Edited by Bertelsmann Stiftung. Gütersloh: Bertelsmann Stiftung, pp. 271-300.

Huber, Stefan. 2003. Zentralität und Inhalt: Ein neues multidimensionales Messmodell der Religiosität. Wiesbaden: VS Verlag für Sozialwissenschaften.

Huber, Stefan. 2009. Religion Monitor 2008: Structuring Principles, Operational Constructs, Interpretive Strategies. In What the World Believes: Analysis and Commentary on the Religion Monitor 2008. Edited by Bertelsmann Stiftung. Gütersloh: Bertelsmann Stiftung, pp. 17-51.

Huber, Stefan, and Odilo Huber. 2012. The Centrality of Religiosity Scale (CRS). Religions 3: 710. [CrossRef]

Huber, Stefan, and Volkhard Krech. 2009. The Religious Field Between Globalization and Regionalization: Comparative Perspectives. In What the World Believes: Analysis and Commentary on the Religion Monitor 2008. Edited by Bertelsmann Stiftung. Gütersloh: Bertelsmann Stiftung, pp. 53-93.

Huber, Stefan, Michael Ackert, and Herbert Scheiblich. 2020. Religiosität in unterschiedlichen Religionskulturen-Vergleiche auf der Basis der Centrality of Religiosity Scale. Cultura \& Psyché. [CrossRef]

Iannaccone, Laurence R. 1998. Introduction to Economics of Religion. Journal of Economic Literature 36: 1465-96.

Kirchmaier, Isadora, Jens Prüfer, and Stefan T. Trautmann. 2018. Religion, Moral Attitudes and Economic Behavior. Journal of Economic Behavior E Organization 148: 282-300. [CrossRef]

Kleibergen, Frank, and Richard Paap. 2006. Generalized Reduced Rank Tests Using the Singular Value Decomposition. Journal of Econometrics 133: 97-126. [CrossRef]

Lehrer, Evelyn L. 2009. Religion, Economics, and Demography. The Effects of Religion on Education, Work, and the Family. London and New York: Routledge.

Lipford, Jody W., and Robert D. Tollison. 2003. Religious Participation and Income. Journal of Economic Behavior E Organization 51: 249-60. [CrossRef]

Lübbe, Hermann. 2004. Religion nach der Aufklärung. München: Fink.

Luhmann, Niklas. 1982. Funktion der Religion. Frankfurt am Main: Suhrkamp.

Mafuta, Lubeme. 2010. Religion and Development in South Africa: An Investigation of the Relationship between Soteriology and Capital Development in an African Initiated Church. Ph.D. dissertation, University of South Africa, Pretoria, South Africa.

Mangeloja, Esa. 2005. Economic Growth and Religious Production Efficiency. Applied Economics 37: 2349-59. [CrossRef]

Marx, Karl. 1972. Critique of Hegel's 'Philosophy of Right'. Cambridge: Cambridge University Press. First published 1843.

Masondo, Sibusiso. 2013. The Crisis Model for Managing Change in African Christianity: The Story of St John's Apostolic Church. Exchange 42: 157-74. [CrossRef]

Masondo, Sibusiso. 2014. The African Indigenous Churches' Spiritual Resources for Democracy and Social Cohesion. Verbum et Ecclesia 35: 1-8. [CrossRef]

Mbeki, Thabo. 2003. Bold Steps to End the 'Two Nations' Divide. ANC Today 3: 22-28.

McCleary, Rachel M., and Robert J. Barro. 2006. Religion and Economy. Journal of Economic Perspectives 20: 49-72. [CrossRef]

Meyer, Lutz. 2004. The Pentecostal Movement as Represented in Breakthrough International an Expression of Missio Dei? A Contribution to an Experimental Pneumatology of Mission. Ph.D. dissertation, University of KwaZulu-Natal, Pietermaritzburg, South Africa. 
Nackerdien, Faeez, and Derek Yu. 2019. A Panel Data Analysis of the Formal-Informal Sector Labour Market Linkages in South Africa. Development Southern Africa 36: 329-50. [CrossRef]

Noland, Marcus. 2005. Religion and Economic Performance. World Development 33: 1215-32. [CrossRef]

Norris, Pippa, and Ronald Inglehart. 2011. Sacred and Secular: Religion and Politics Worldwide, 2nd ed. Cambridge: Cambridge University Press.

Ntuli, M., and M. Wittenberg. 2013. Determinants of Black Women's Labour Force Participation in Post-Apartheid South Africa. Review of Economics and Statistics 22: 347-74. [CrossRef]

Öhlmann, Philipp, and Silke Hüttel. 2018. Religiosity and Household Income in Sekhukhune. Development Southern Africa 36: 179-93. [CrossRef]

Öhlmann, Philipp, Marie-Luise Frost, and Wilhelm Gräb. 2016. African Initiated Churches' Potential as Development Actors. HTS Teologiese Studies/Theological Studies 72: 1-12. [CrossRef]

Öhlmann, Philipp, Wilhelm Gräb, and Marie-Luise Frost. 2020. Introduction: African Initiated Christianity and Sustainable Development. In African Initiated Christianity and the Decolonisation of Development: Sustainable Development in Pentecostal and Independent Churches. Edited by Philipp Öhlmann, Wilhelm Gräb and Marie-Luise Frost. London: Routledge, pp. 1-30.

Oosthuizen, Gerhardus C. 1988. Interpretation of Demonic Powers in Southern African Independent Churches. Missiology 16: 3-22. [CrossRef]

Oosthuizen, Gerhardus C. 1997. African Independent Churches and Small Businesses: Spiritual Support for Secular Empowerment.. Pretoria: Human Sciences Research Council.

Pargament, Kenneth I. 1997. The Psychology of Religion and Coping: Theory, Research, Practice. New York: Guilford Publications.

Pargament, Kenneth I. 2012. Religion and Coping: The Current State of Knowledge. In the Oxford Handbook of Stress, Health, and Coping. Edited by Susan Folkman. Oxford: Oxford University Press.

Pargament, Kenneth I., and Hisham A. Raiya. 2007. A Decade of Research on the Psychology of Religion and Coping: Things We Assumed and Lessons We Learned. Psyke E Logos 28: 742-66.

Permani, Risti. 2011. The Presence of Religious Organisations, Religious Attendance and Earnings. Evidence from Indonesia. The Journal of Socio-Economics 40: 247-58. [CrossRef]

Pew Forum. 2010. Tolerance and Tension: Islam and Christianity in Sub-Saharan Africa. Washington, DC: Pew Forum on Religion \& Public Life, Available online: https://www.pewforum.org/wp-content/uploads/sites/7/2010/04/sub-saharan-africa-full-report.pdf (accessed on 8 December 2020).

Pickel, Gert. 2013. Religion Monitor: Understanding Common Ground. An International Comparison of Religious Belief. Gütersloh: Bertelsmann-Stiftung.

Roodman, David. 2011. Fitting Fully Observed Recursive Mixed-Process Models with Cmp. Stata Journal 11: 159-206. [CrossRef]

Sanderson, Eleanor, and Frank Windmeijer. 2016. A Weak Instrument F-Test in Linear IV Models with Multiple Endogenous Variables. Journal of Econometrics 190: 212-21. [CrossRef] [PubMed]

Saroglou, Vassilis. 2021. The Psychology of Religion. Milton Park: Routledge.

Schilling, Heinz. 2016. Martin Luther. Rebell in einer Zeit des Umbruchs. München: C.H. Beck.

Schlemmer, Lawrence. 2008. Dormant Capital: The Pentecostal Movement in South Africa and Its Potential Social and Economic Role. Johannesburg: Centre for Development and Enterprise.

Selinger, Leah. 2004. The Forgotten Factor: The Uneasy Relationship Between Religion and Development. Social Compass 51: 523-43. [CrossRef]

Silver, Daniel. 2006. Religion without Instrumentalization. European Journal of Sociology 47: 421-34. [CrossRef]

South African Social Security Agency. 2016. You and Your Grants. 2016/17. Pretoria: South African Social Security Agency.

Spenkuch, Jörg L. 2017. Religion and Work: Micro Evidence from Contemporary Germany. Journal of Economic Behavior E Organization 135: 193-214. [CrossRef]

Statistics South Africa. 2004. Census 2001. Primary Tables 1996 and 2001 Compared. Report no. 03-02-05 (2001), etc. Pretoria: Statistics South Africa.

Statistics South Africa. 2014. Survey of Employers and the Self-Employed, 2013: Statistical Release P0276. Pretoria: Statistics South Africa.

Statistics South Africa. 2017. Poverty Trends in South Africa: An Examination of Absolute Poverty Between 2006 and 2015. Pretoria: Statistics South Africa.

Statistics South Africa. 2018. Quarterly Labour Force Survey. Quarter 4: 2017; Pretoria: Statistics South Africa. Available online: http: / / www.statssa.gov.za/publications / P0211/P02114thQuarter2017.pdf (accessed on 21 February 2018).

Steen, Todd P. 2004. The Relationship Between Religion and Earnings. Recent Evidence from the NLS Youth Cohort. International Journal of Social Economics 31: 572-81. [CrossRef]

Stock, James H., and Motohiro Yogo. 2005. Testing for Weak Instruments in Linear IV Regression. In Identification and Inference for Econometric Models: Essays in Honor of Thomas Rothenberg. Edited by Donald W. K. Andrews and James H. Stock. Cambridge: Cambridge University Press, pp. 80-108.

Swart, Ignatius. 2006. Churches as a Stock of Social Capital for Promoting Social Development in Western Cape Communities. Journal of Religion in Africa 36: 346-478. [CrossRef]

Swart, Ignatius. 2017. Social Capital, Religious Social Capital and the Missing Element of Religious Ritual. Religion and Theology 24: 221-49. [CrossRef] 
Szcześniak, Małgorzata, Zdzisław Kroplewski, and Roman Szałachowski. 2020. The Mediating Effect of Coping Strategies on Religious/Spiritual Struggles and Life Satisfaction. Religions 11: 195. [CrossRef]

Thomas, Linda E. 2007. Under the Canopy: Ritual Process and Spiritual Resilience in South Africa. Columbia: University of South Carolina Press.

Thomsen, Jørgen. 2017. The Sustainable Development Goals as Space and Sparring Partner for Religious Actors in Development. Ny Mission 32: 25-33.

Turner, Harold W. 1980. African Independent Churches and Economic Development. World Development 8: 523-33. [CrossRef]

Ungureanu, Ileana, and Jonathan G. Sandberg. 2010. 'Broken Together': Spirituality and Religion as Coping Strategies for Couples Dealing with the Death of a Child: A Literature Review with Clinical Implications. Contemporary Family Therapy 32: 302-19. [CrossRef]

van Hoorn, André, and Robbert Maseland. 2013. Does a Protestant Work Ethic Exist? Evidence from the Well-Being Effect of Unemployment. Journal of Economic Behavior \& Organization 91: 1-12. [CrossRef]

Weber, Max. 1958. The Protestant Ethic and the Spirit of Capitalism. New York: Scribner. First published 1920.

Wepener, Cas, Ignatius Swart, Gerrie ter Haar, and Marcel Barnard. 2010. The Role of Religious Ritual in Social Capital Formation for Poverty Alleviation and Social Development: Theoretical and Methodological Points of Departure for a South African Exploration. Religion and Theology 17: 61-82. [CrossRef]

Woolcock, Michael. 1998. Social Capital and Economic Development: Toward a Theoretical Synthesis and Policy Framework. Theory and Society 27: 151-208. [CrossRef]

Wooldridge, Jeffrey M. 2010. Econometric Analysis of Cross Section and Panel Data. Cambridge, MA: MIT Press.

World Bank. 2018. Overcoming Poverty and Inequality in South Africa. An Assessment of Drivers, Constraints and Opportunities. Washington, DC: World Bank.

Zapata, Oscar. 2018. Turning to God in Tough Times? Human Versus Material Losses from Climate Disasters in Canada. Economics of Disasters and Climate Change 2: 259-81. [CrossRef] 